\title{
"Elder Brother Tobacco": Traditional Nicotiana Snuff Use among the Contemporary Tzeltal and Tzotzil Maya of Highland Chiapas, Mexico
}

\author{
Kevin P. Groark \\ Department of Anthropology, Macquarie University \\ NSW 2109, Australia \\ kevin.groark@mq.edu.au
}

Submitted: $1 / 1 / 2016$

Revised: $1 / 25 / 2017$

Email: kevin.groark@mq.edu.au

Note: This is a preprint copy of the final accepted version on this book chapter. When citing or quoting, please reference the final print copy [available Sep 2017] for page numbers and final text. If you do not have access to the final print copy, please email me for a PDF copy (kgroark@gmail.com):

Final Publication Citation:

Groark, Kevin P. 2017. "Elder Brother Tobacco": Traditional Nicotiana Snuff Use among the Contemporary Tzeltal and Tzotzil Maya of Highland Chiapas, Mexico. Forthcoming in Breath and Smoke:Tobacco Among the Maya (Keith Eppich and Jennifer A. LoughmillerCardinal and, eds.). University of New Mexico Press: Albuquerque, NM. [Expected publication date, Sep 2017] 


\title{
"Elder Brother Tobacco": Traditional Nicotiana Snuff Use among the Contemporary Tzeltal and Tzotzil Maya of Highland Chiapas, Mexico
}

\author{
KEVIN P. GROARK \\ Department of Anthropology, Macquarie University \\ NSW 2109, Australia \\ kevin.groark@mq.edu.au
}

\begin{abstract}
In Tzotzil and Tzeltal Maya communities throughout the highlands of Chiapas in southeastern Mexico, a potent oral snuff composed of fresh tobacco (Nicotiana tabacum L.) and slaked lime (calcium hydroxide) is used in a wide range of therapeutic, ritual, and protective contexts. The use of this tobacco snuff-referred to in Tzotzil Maya as “angel” (anjel), "elder brother" (bankilal), "great old man” (muk'ta mol), or simply "tobacco" (moy) — appears to date back to the Classic Maya, and represents continuity in Mayan tobacco culture spanning more than a thousand years. Despite the central importance of this plant in highland Maya medicine and ritual, its use has not previously been documented in any systematic manner. Accordingly, this chapter seeks to present a comprehensive overview of traditional highland Maya tobacco culture among the contemporary Tzotzil and Tzeltal Maya of highland Chiapas, exploring the cultural significance in this quintessentially Amerindian plant in the domains of ethnomedicine, ritual, folklore, and mythology.
\end{abstract}

\section{Introduction}

Among the Ancient Maya, Nicotiana was viewed as a sacred plant, closely associated with deities of earth and sky, and used for both visionary and therapeutic ends. The contemporary Tzeltal and Tzotzil Maya of Highland Chiapas (Mexico) are heirs to this ancient ethnobotanical tradition, maintaining a complex tradition of tobacco use and folklore. In Maya communities throughout the highlands, the tobacco plant is viewed as a primordial medicine and a powerful botanical "helper" or "protector" with uses both mundane and divine. Whole leaves are boiled, wilted, mashed, and bruised in the preparation of medicinal plasters and teas. Fresh leaves are mixed with slaked limestone and pounded into a potent green mash, yielding a potent oral snuff that serves as a medicine, a stimulant, an intoxicant, as well as a protective agent. 
This tobacco-lime snuff preparation—referred to in Tzotzil as "angel" ('anjel), "elder brother" (bankilal), "great old man" (muk'ta mol), or simply "tobacco" (moy)-forms the prototypical referent for highland Maya thinking about tobacco. Stored and carried in small, highly polished gourds, this tobacco snuff is part of an unbroken tradition of Maya tobacco use spanning thousands of years. In the pages that follow, I present a comprehensive ethnographic overview of contemporary highland Maya (Tzeltal-Tzotzil) tobacco culture, exploring the therapeutic, protective, and ritual uses of Nicotiana tabacum in both Tzeltal and Tzotzil Maya communities. ${ }^{1}$

\section{ETHNOBOTANICAL DESCRIPTION}

Nicotiana tabacum Linnaeus, referred to colloquially as tobacco, has been welldescribed in the botanical literature (Goodspeed 1954:372-75; see also Breedlove and Laughlin 1993:242). ${ }^{2}$ Based on genetic and distributional data, Nicotiana appears to have spread to the Central Mexican highlands from its origin in Andean South America (Goodspeed 1954:8; Wilbert 1987:2). Cultivated and semi-cultivated forms are common among horticulturalists throughout Southern Mexico who use the plant for medicinal and recreational purposes. In the Chiapas highlands, Nicotiana plants are not intentionally cultivated; rather, they grow wild in disturbed soil in house gardens, corrals, and along trails. Although tobacco is locally classified as a wild plant, seedlings are often collected in the wild and transplanted to house gardens, suggesting that tobacco might best be considered a semicultivar in this region (Breedlove and Laughlin 1993:242). Indeed, prohibitions exist against cutting down the plants; should a man destroy a tobacco plant, it is said that invisible stinging caterpillars will attack the offender while he works in his field, and the resulting wounds will heal only after the offender ingests a mashed green tobacco leaf (Breedlove and Laughlin 1993:242).

Although awareness of tobacco snuff preparation and use is distributed universally throughout contemporary highland Maya communities, the eastern Tzeltal-speaking communities (particularly Tenejapa, Oxchuc, Chanal, and Cancuc) preserve the most vigorous traditions of tobacco use. In more distant parts of this region, tobacco gourds are still carried by old men, and snuff use remains common in everyday life as well as in ritual contexts. In the western Tzotzil communities, in contrast, tobacco use has become much 
more restricted; while it remains central to many ritual and therapeutic practices, daily use as a stimulant is now rare.

Tobacco Nomenclature.-The tobacco plant is generically referred to as moy in Tzotzil and may in Tzeltal, the two principal languages spoken in the region. These variants derive from a common proto-Tzeltal-Tzotzil root *may, which diversified into the two terms used today (Kaufman 1972; Berlin and Berlin 1996:297). This name refers to the living Nicotiana plant, the harvested leaves, as well as the ground tobacco-lime chewing tobacco preparation referred to in local Spanish as pílico ('tobacco powder or snuff').

In addition to this generic name, several metaphorical names (referring principally to prepared tobacco snuff) are in circulation. In several highland communities, tobacco is referred to as "elder brother" (bankilal) or "angel" ('anjel). Other less common names are also used: in Zinacantán, chewing tobacco is sometimes referred to as "great old man" (muk'ta mol), and when prepared as a curing salve used in the treatment of supernaturallyinduced aching and swelling of the legs it is referred to as "lord" (ojov) (Breedlove and Laughlin 1993:242). A similar name is found in the Tzotzil-speaking community of Venustiano Carranza, where tobacco is called "holy man" (ch'ul winik) (Berlin et al. 1990:99). These names appear to refer specifically to the soul essence of tobacco, and are only applied to the prepared tobacco-lime mixture (which is understood to be the most potent form of the plant). This preference for indirect or metaphorical names is linked to respect for the powerful soul of tobacco, which can become offended if referred to directly as moy, or “tobacco plant." In a later section I will explore the mythological associations referenced by these enigmatic names.

Nicotiana Ethnotaxonomy. - Two folk varietals of Nicotiana are locally distinguished based on the color of the flowers, which occur in both pink and white forms (see Figure 1). In the Tzotzil community of Chamula, the pink-flowered variety known as 'male tobacco' (vinikil moy) is considered most potent, and is the only one used for medicinal or protective purposes. The white-flowered 'female tobacco' (antzil moy), in contrast, is said to "lack strength" (mu'yuk yip), and to "be of no use" (mu xtun) or "to be ineffective" (mu sbalin). Breedlove and Laughlin (1993) describe a similar pattern of use in the nearby Tzotzil township of Zinacantán. In contrast, the Tzeltal community of Tenejapa is reported to accord 
the white-flowered plant greater medicinal strength, and this is preferred variety for use in the preparation of tobacco snuff (Berlin and Berlin 1996:299).

While discussing the difference in potency between the two Nicotiana varieties, one of my Chamula Tzotzil collaborators — an j'ilol, or traditional curer-explained:

There are two kinds of tobacco: white-flowered (sak snich) and pink-flowered (tzoj snich). The pink-flowered one comes from Our Father in Heaven [the Christ-Sun deity]. It's much better [because] it has color, it has strength. As for the white flowered one, it is "women's tobacco" (antzil moy). It is white because the woman [Our Mother in Heaven, the Moon-Mary deity] handled it long ago... she planted this one, she had her own tobacco back then. But the flower [of her tobacco] was white, not pink. It has strength, but just a little, it seems. [This is because] the woman had less power. But Our Father, he had much more strength. It's the same with tobacco - the female [variety] has less strength... Now we only use the pink-flowered one [in Chamula].

This short narrative explains the genesis of the two varieties (as well as the variation in their "power" or strength) in terms of the gendered differences between the progenitor deities said to have cultivated the first tobacco plants. Like human beings, the "male tobacco" is viewed as stronger and more effective than its female counterpart. From a botanical perspective, the two "varieties" are identical in all respects, save for the color of the flowers. Moreover, there is no essential difference between the two types; the seeds from a pink-flowered plant can yield either white or pink daughter plants.

\section{PREPARATION AND USE OF TRADITIONAL TOBACCO SNUFF}

As mentioned, most highland Maya familiar have one or more tobacco plants growing in their fields or near their homes. In addition to providing a ready source of leaves for the preparation of tobacco snuff and medicine, belief in the plant's ability to repel malevolent entities makes it a desirable component in house gardens (Breedlove and Laughlin 1993:242). ${ }^{3}$ Amongst "traditionalist" Tzotzil and Tzeltal, tobacco use centers on 
the ingestion of a coarsely ground mixture of fresh tobacco leaves and slaked lime. While this preparation would be referred to in English as a form of "chewing" tobacco, it is more properly described as "sucking" tobacco, specifically as an oral tobacco snuff (IARC 2007:47).

In everyday use, a small quantity of the ground tobacco-lime preparation is poured into the palm from a highly polished gourd, then tossed into the mouth, where it is held either on the tongue or between the cheek and the jaw for an extended time (Figure 2). The juice from the tobacco quid is swallowed. This form of tobacco ingestion is described as "eating" (-lo'), rather than chewing or sucking. Once the tobacco has been exhausted, it is either swallowed or rubbed on a rock or tree; spitting the spent quid to the ground is said to be disrespectful, offending the soul of the tobacco plant.

Anyone who has used freshly prepared green tobacco can attest to its potency: swallowing the juice produces a marked burning sensation in the nasopharyngeal region, often accompanied by a burning constriction (-tzukilan) in the upper chest, leading to shallow respiration and shortness of breath (suk o'nton), sometimes accompanied by mild fits of hiccupping (jik'ubajel), deriving from stimulation of the trigeminal nerve. Soon after, as the nicotine enters the bloodstream and gains access to the brain, mild vertigo begins, lasting 5 to 10 minutes. This is referred to in Tzotzil as "becoming drunk on tobacco" (yak'ub ta moy), or "to be rendered dumb" (-bolibtas). Referring to its intoxicating effects, freshly prepared tobacco snuff is sometimes referred to in Tzotzil as a "stupifier" (bolibtasobil) (Breedlove and Laughlin 1993:582). Several informants reported that their "head grows large" (-muk'ib jol) in the minutes after ingestion, a reference to tingling of the scalp in which the hair follicles feel as though they are standing on end. Indeed, generalized piloerection is typical when using tobacco. Following this, a feeling of calm, stimulated focus predominates. ${ }^{4}$

Preparation of Tobacco Snuff.-In Chamula, the production of tobacco is limited to men, who prepare it for personal and family use; although women can use tobacco, they do not usually prepare it. This gender-restriction is not universal; in both Chanal and Oxchuc, widows and older unmarried women prepare their own tobacco. In all communities, however, both men and women use the same locally preferred variant, usually the pink "male" variety. Preparation of the mixture is limited to Monday, Wednesday, Friday, or Saturday (the days when the saints and other protective deities are guarding the earth from 
malign influences); preparing the mixture on other days is said to yield a tobacco without strength, or worse yet, one that will sicken the user. A Chamula man explained to me that Our Father in Heaven - the Sun-Christ deity — bestows his blessing on the tobacco during preparation, thereby conferring power upon the mixture, and transforming mere tobacco (moy) into the supernaturally powerful "elder brother" (bankilal) or "angel” (anjel).

In traditional practice, neither the leaves nor the prepared tobacco snuff can be sold; rather, they must be given freely. Should the recipient of this gifted tobacco express thanks, the tobacco will be ruined; rather than curing and protecting the user, the plant will inflict diarrhea and bloating. These prohibitions on the exchange of tobacco suggest that, in the past, ritualized sharing may have been more fully integrated into everyday social exchanges - much like formalized coca leaf use in contemporary Andean South America.

The preparation process can be divided into four stages:

1. Leaf Collection.-Mature Nicotiana leaves (yanal moy) are harvested when needed. As a rule, only broad, fresh, green leaves are harvested-yellow or dried leaves are never used. Leaves are left to cure in the shade for a day or two, but are never allowed to dry. During this short "resting" period, much of the moisture in the leaves dissipates, facilitating preparation, and allowing the chemical constituents to concentrate. If the leaves are processed immediately after harvesting, they are said to lose of much of the their "strength" (yip) when the bioactively-rich juice is expressed and discarded. In general, 18 medium leaves will produce enough snuff to fill an average tobacco gourd.

2. De-Veining.- After resting for a day or two, the leaves are cleaned and carefully de-veined. The lamina is stripped out from between the coarse veins and stem, and collected in a basket, cloth, or wood box (Figure 3a). The veins and stem-too fibrous and moist to be ground into a palatable chewing tobacco - tend to be discarded.

3. Pounding.-After the lamina has been stripped off, it is pounded (tenbil) into a moist pulp with a stone, axe handle, or some other suitable instrument. Once reduced to a course mash, the leaves are often further ground with a stone mano. The final 
preparation is of medium coarseness, similar in texture to ground oregano leaves (Figure 3b).

4. Addition of Admixtures.-Once reduced to a course mash, calcium hydroxide in the form of slaked limestone (tan) is added to the leaves as an alkalizing agent, and pounding continues (Figure $3 \mathrm{c}$ ). ${ }^{5}$ This lime is locally produced and is traditionally sold in the form of rough stone cobbles, which must first be ground into a powder. Once mixed with tobacco, the slaked lime is referred to metaphorically as "chile pepper" (ich) — a reference to the "heat" and piquancy it confers to the mixture. Should it be called by its "true" name (tan) during preparation, it is said that the tobacco will lack strength. Nowadays, commercially produced lime (kaligra) is often substituted for the locally produced slaked limestone. At this stage, other additives (such as camphor or orange rinds) are sometimes mixed in to increase the "heat" of the tobacco, to prepare it as a special remedy, or merely to change its flavor. While mixing tobacco with camphor is said to make it "hotter" (mas $\boldsymbol{k}^{\prime} \mathbf{i x i n}$ ), many people use admixtures to produce a more agreeable flavor (mas lek smuil). When I asked an older "traditionalist" man from Chamula about this practice, he felt that it was damaging to tobacco's power: "It's not original, mixed up like that. It's no good. Mixed [with substances other than slaked lime], it changes the flavor/odor of the tobacco, it no longer serves as a 'helper' (koltaob-bail), it can no longer defend (-poj) the person who carries it... It can't be used [for protection] because it's been adulterated (kapal $\boldsymbol{x a}$ ), it's been messed with (utilanbil)." too hot, its piquancy can be reduced by adding more tobacco leaves.

The Tobacco Gourd.-After the tobacco has been pounded to the desired coarseness, it is packed into a small, highly polished gourd for easy storage, transportation, and use (Figure 3d). In past times, most highland Maya men carried these little gourds in their shoulder bag as they went about their daily business. Made from one of several forms of Lagenaria siceraria (Curcurbitaceae), these simple undecorated containers are known as stzual moy ('tobacco's gourd'), or more literally, yavil moy ('tobacco's place/vessel'). While tobacco gourds are rarely carried nowadays, they remain the universally favored container for tobacco snuff. In fact, they are the only containers suitable for freshly 
ground tobacco; porous vessels (such as those made from ceramic) draw the juice or "power" out of the tobacco, and fresh snuff quickly rots in non-porous containers (such as bottles or plastic containers), ruining the flavor and potency of the preparation.

Like the tobacco plant, the carrying gourds are gendered. "Male gourds" (vinik tzu or stot) tend to be shaped like large chili peppers, and are distinguished by their long, pointed "tail" (neil). "Female gourds" (antzil tzu or sme'), in contrast, are rounded or tear-shaped (volvol) in form (Figure 4a). One man explained the difference in the following humorous terms: "The female gourd is round, it doesn't have a penis [referring to its lack of a long "tail"], it's sort of like a breast..." gesturing to the small nub at the base of the gourd, he added, "this here is the nipple." The use of tobacco gourds is typically limited to men, who can carry either male or female gourds, depending on personal preference. Some people maintain that the male gourds are more desirable, since they have "more power" (owing to their associations with maleness, metaphorical "heat," as well as male genitalia). The typical tobacco gourd is 4-5 inches in length, with a maximum width of 3-4 inches. When new, the containers are a matte honey-yellow color, but after years of use and storage in smoky dwellings, they gain a beautiful, deeply polished, red-brown. ${ }^{7}$

In several Tzeltal communities, tobacco gourds were traditionally paired with a long deer bone spatula or needle (sbakel stzual may, 'the tobacco gourd's bone') attached by a cord of leather, cotton, or henequen fiber. This bone spatula was used to break up the hard balls of tobacco that form inside the gourd as the moist tobacco dries. Gourds with bone spatulas appear to have been used throughout the Tzeltal area (especially in the communities of Tenejapa, Cancuc, Oxchuc, and Chanal), but are now quite rare-a full day of searching in the Tzeltal community of Tenejapa produced only a single example (see Figure 4b). This specimen was no longer in use- it had belonged to the owner's deceased father, and was now stored next to the cross on the household altar. To my knowledge, Tenejapa is the only community in which the old deer bone tobacco dippers can still be found, however rarely. In most Tzotzil communities, a simple stick (referred to as sjotz'obil moy, 'tobacco crusher') is used for this purpose, as needed, then discarded.

This tradition of personal tobacco containers appears to derive from the Ancient Maya of the Classic period. Carlson (2007a, 2007b:11) has argued that a type of small ceramic vessel common during the Middle to Late Classic period—often referred to in the literature as "poison bottles" or "pilgrim's flasks" - served as containers for ground tobacco. 
These ceramic vessels are typically flask-shaped (rounded when viewed from the front, but compressed in profile) with a flat base, often with lateral handles for suspension. Many feature codex-style scenes and inscriptions, and some are adorned with tobacco leaf motifs or deities. The presence of enema scenes and specific inscriptions identifying the flasks as "the dwelling place/home of his/her tobacco" (y-otoot 'u-maay) clearly indicate that these vessels were used as containers for various forms of tobacco, including snuff, tobacco juice, or enema liquids derived from tobacco leaf infusions (Stuart 2005; see also Houston et al. 2006:105, 114-116; Carlson 2007b:12). Recently, chemical analysis of one such flask revealed the presence of nicotine alkaloids, providing the first direct evidence tobacco storage in a vessel bearing the $\boldsymbol{y}$-otoot ' $\boldsymbol{u}$-maay inscription (Zagorevski and LoughmillerNewman 2012; Loughmiller-Newman and Zagorevski n.d.).

During the final years of the Late Classic period, these bottles were widely traded throughout the Maya region, suggesting not only exchange of vessels, but more importantly, of the contents of these vessels (Houston et al. 2006:116). While the contemporary highland Maya store and transport tobacco snuff exclusively in the small gourd containers described above, it is interesting to note that an Early Classic "poison bottle" executed in the form of a gourd was recovered from Uaxactun (Smith 1955:fig 66a-7; cited in Houston et al. 2006:114); similarly, Deal (1998:199) identified antique ceramic containers shaped like gourds from the Tzeltal community of Chanal. He reports that, while no longer manufactured or used, these vessels served as temporary containers for, among other things, ground tobacco (ibid.). The use of gourd-shaped ceramic vessels for tobacco storage in the eastern Tzeltal region suggests a line of continuity between ancient Maya ceramic tobacco flasks, the ceramic gourds identified in Chanal, and the gourd containers typical of the contemporary highland Maya.

\section{TOBACCO AS “POWERFUL BOTANICAL”}

In a world dominated commercial tobacco, we have lost our connection to the powerful physiological effects and mind-altering powers of Nicotiana. Among the contemporary Tzotzil and Tzeltal Maya, however, awareness of the plant's physiotransformative power remains strong. Indeed, native tobacco is regarded as a prototypical 
medicine or "powerful substance" (poxil), offering a range of therapeutic and protective benefits.

Despite potential health risks, traditional tobacco use offers many benefits to people who spend much of their lives working out of doors. At controlled doses, the nicotine alkaloid has been shown to possess many beneficial properties; it reduces fatigue and pain, eases hunger, reduces the surface temperature of the skin, and produces marked central nervous system stimulation, memory-enhancement, elevation of mood, and an increase in attentional focus (Benowitz et al. 1990; Badio and Daly 1994; McGehee et al. 1995; McGehee and Role 1996; Newhouse et al. 2004). While nicotine toxicity (marked by racing heartbeat, sweating, nausea, and vomiting) often accompanies high levels of tobacco use, even these toxic effects can be harnessed for culturally significant purposes. At high doses nicotine is capable of inducing altered mental states and visionary experiences (see Janiger and Dobkin de Rios 1973, 1976; Wilbert 1987). Ritual intoxication was practiced by the Classic Maya, who appear to have sought visionary states through the administration of tobacco juice enemas (Thompson 1946; Robicsek 1972; de Smet and Hellmuth 1986; Carlson $2007 a, b)$. Contemporary ritual use of tobacco in combination with alcohol (which catalyzes the absorption and bioavailability of nicotine) suggests some continuity, albeit much attenuated, with this earlier visionary tradition.

In a recent study of diachronic semantics, Maffi (1996) has convincingly argued that the proto-Tzeltal-Tzotzil term for medicine (*pox) — which she glosses as "powerful substance"-referred prototypically to the therapeutic use of tobacco. Today, the word pox refers universally to locally produced cane liquor; yet entries in Colonial dictionaries consistently link pox to various medicinal substances, most of which were-like tobaccosmeared or rubbed on the body, a form of administration that remains common in the Chiapas highlands (ibid.). Contemporary Zinacantec Tzotzil verb forms derived from the word pox retain this close connection to tobacco; the intransitive verb -poxin means "treat self with tobacco, anoint body" while the transitive form -poxta is glossed as "administer medicine, prepare (chewing tobacco by adding lime to the tobacco)" (Laughlin 1975:286; cited in Maffi 1996:33). Similarly, the derived term jpoxtavanej (herbal curer, 'one who cures with powerful substances') remains in circulation throughout the highlands.

In highland Maya ethnomedicine, a key element in botanical therapeutic strength is the ability to "attack" or "overpower" an illness, a quality usually associated with both bitter (ch'a) and piquant (ya) tasting substances (Brett 1994). Among the Tzotzil, these two 
therapeutic organoleptic qualities are considered typical of tobacco, serving as manifest indications of the "inherent power" (-ip) and "heat" (-k'ixin) of both the plant and the chewing tobacco mixture (Berlin and Berlin 1996:299). ${ }^{8}$ The quality most closely associated with tobacco's ability to protect the user from supernatural threats is its strong odor (ik, smuil), a quality shared by garlic (which is often used in conjunction with tobacco in the preparation of protective mixtures).

Tobacco as Quasi-Agentic Botanical._Like all plants, Nicotiana is said to possess an essential soul (ch'ulel) and is therefore capable of feeling, emotion, and at times, of agentive action. If tobacco is shown a lack of respect, people believe that it can inflict sickness upon the one who offended it. Negative comments about the plant's strong smell are particularly offensive, resulting in constipation and severe abdominal swelling (pumel, t'imel), a condition that can be cured only by eating more tobacco. Interestingly, special agentive verb forms are used when referring to tobacco's ability to cause illness: when causing constipation, the verb used is -makesvan ('to stop someone up'), while the infliction of swelling (said to result from thanking someone for gifted tobacco) is expressed by means of the verb -sit'esvan ('to cause someone to swell or bloat') (Breedlove and Laughlin 1993:485). Such verb forms can be used only when referring to a subject with agentic potential, such as a person, an animal, or in this case, a particularly powerful plant. A humorous tale from Zinacantán highlights the dangers of disrespecting tobacco, while poking fun at the non-Indian's ignorance of the medicinal virtues:

Long ago a man went to the coffee fincas [plantations]. He took his net [bag] along with him to work. He set it down and took out his tobacco. He put some in his mouth. The owner of the finca saw him. "Why do you eat horse shit?" he asked. "No, this is medicine" [the man replied]. The owner said, "No, it's just horse shit." They worked until two in the afternoon. The owner went home. He fell sick. He felt worse and worse. Then he sent for [the Indians] and begged them to cure him. At last they agreed, on condition that he give them two days of rest, because in those days the workers weren't paid. They gave him the tobacco to take, but in a bowl of urine. After they urged him and urged him to drink it, he swallowed it down. He let a big fart and got well. He bought their tobacco and respected it from then on." (Breedlove and Laughlin 1993:242) 
A similar story centering on the Mexican's "discovery" of tobacco's power is found among Tenejapa Tzeltal:

...a mestizo [non-Indian Mexican] who was traveling with a group of Indians first ridiculed them when he saw them rubbing the [tobacco] snuff on themselves [for protection]. Later, however, he became seriously ill [from having disrespected the plant], and recovered only because he let tobacco be administered to him. From then on, he was as fervent an admirer of tobacco as the Indians." (Maffi 1996:42; footnote 24)

While these brief stories illustrate the dangers of offending tobacco, they also serve as stories of ethnic ownership: tobacco is viewed as a quintessentially Indian "secret," a powerful protective and therapeutic ally whose virtues are unknown in the surrounding Mexican community. Moreover, this ignorance of tobacco's power often comes at a price; having disrespected the plant, the Mexican becomes a figure of ridicule when he is laid low with explosive diarrhea and painful abdominal swelling. Indeed, stories abound of disgruntled workers sprinkling tobacco on the backs of abusive crew bosses during the days of wage labor on lowland coffee plantations. Once the Mexican oppressor has been brought down by illness, his Indian peons demonstrate their superior knowledge and ability by restoring his health with the same tobacco that caused the illness.

\section{THERAPEUTIC USES OF TOBACCO}

Tobacco is viewed as "medicine" (poxil) — a primordial resource for restoring health and protecting from misfortune or threat. In therapeutic contexts, Nicotiana is prepared and administered in many forms: jaxbil (rubbed on body), lo'bil (eaten), k'ixnabil (wilted by fire), atinbil (bathed in), uch'bil (drunk), tub'tabil (sprayed from mouth/spit out), and pak'bil or lambil (applied as a bandage or compress). In many cases, the leaves are pounded along with ash or slaked lime, then added to water or cane liquor, and drunk as a tea. Warm tobacco leaves are also commonly applied as plasters or compresses, sometimes with 
admixtures. The plant is always administered fresh, and the leaf is the only part of the plant that is used.

Throughout the highlands, tobacco is the most commonly used remedy for a wide range of gastrointestinal ailments (Berlin and Berlin 1996:297). In the treatment of stomachache, ground tobacco is drunk with warm water. Principal admixtures for the treatment of abdominal pain include garlic cloves (axux; Allium sativum), the leaves of Baccharis vaccinioides (mes te'), and the leaves of Lagascea helianthifolia (papan te') (Berlin and Berlin 1996:301). In Zinacantán, dried chili is added to the decoction to increase its "heat" and therapeutic potential (Breedlove and Laughlin 1993:243).

Several tobacco-based remedies are recognized for the alleviation of painful abdominal bloating (pumel, t'imel): the juice from chewing tobacco is swallowed, the powder rubbed on the belly, or mixed with water and drunk. To cure "wind" or aire (ik'), ground tobacco snuff is "eaten," drunk as warm infusion, or rubbed on the affected body part. In Zinacantán, a tobacco-garlic-urine mixture is drunk in the treatment of constipation and urinary stoppage (makel), and intestinal worms are eliminated by applying tobacco leaves to the stomach in the form of a cross (Breedlove and Laughlin 1993:242-3).

In the treatment of swelling and/or aching of the foot and leg induced by contact with a supernatural being or witch (poslom, potzlom), a mixture of tobacco, garlic, and women's urine is massaged onto the affected body part following therapeutic bloodletting (Breedlove and Laughlin 1993:243). More simply, the limb may be rubbed with tobacco, alcohol, and garlic, then wrapped in a cloth. Plasters of fire warmed-wilted leaves are also used in the treatment of the condition. In Oxchuc, warmed plasters of tobacco leaves-sometimes mixed with leaves from Brugmansia sp.- - are used in the treatment of bone breaks, sprains, and bruises. This treatment is administered inside of the family steambath, where the warm moist heat of the bath combines with the "heat" of the plant to relax tensed muscles, facilitating therapeutic massage or other manipulations (see Groark 1997, 2005).

In both Oxchuc and Chamula, tobacco leaves are used in the treatment of a form of aggressive madness known as chuvaj. ${ }^{9} \quad$ Following therapeutic bloodletting from the forehead - intended to expel the "stupid blood" (bol ch 'ich') that precipitates the conditionraw tobacco leaves are used to wipe the blood away from the small wounds. In Chamula, a mixture of ground tobacco and garlic cloves in a base of warm cane liquor serves the same purpose. The juice and odor of the tobacco repels the evil forces that might invade the patient's head in the form of "aires," thereby preventing the condition from recurring or 
worsening. The blood expelled from the incisions is said to carry a pathogenic "vapor" (sjob) or "smoke" (sch'ailal) that can infect others. For this reason, children are not allowed to observe bloodletting, and any adults present during the procedure must rub tobacco and garlic over their bodies to protect against this sickening blood vapor (see Groark [1997:57-58, 65] for additional information on therapeutic bloodletting).

Breedlove and Laughlin (1993:243) report additional uses for tobacco in the Tzotzil community of Zinacantán: a mixture of tobacco and warm water is drunk as a purgative to "vomit up" tuberculosis (sak obal); taken with cold water, tobacco serves as an abortifacient; the worm that is said to cause toothaches and dental caries can be killed with tobacco juice, and the same juice can be dripped in the eye to cure yellow spots that sometimes appears in the sclera. Dermatological ailments treated with tobacco (often mixed with garlic) include gangrene (mos), mange (sep'), and boils (chin) (ibid.).

Commenting on its diverse therapeutic applications, Tzotzil-speaking man from Chamula concluded: "It's a strong curer, this [tobacco], a strong medicine-it's not just for you to eat [recreationally]..." (ep jpoxtavanej li'e, ep poxil, ma'uk no'ox sventa chalo'e). The use of the term "curer" (jpoxtavanej, 'one who cures with medicines/powerful substances') in this context is revealing: it is normally applied to people who cure with herbal medicines. Describing tobacco in this way suggests that it possesses an inherently curative potential, one that exists quite apart from the skills or "gifts" of the person administering it.

\section{MAGICO-PROTECTIVE USES OF TOBACCO}

Throughout the highlands, tobacco is accorded great respect as a personal protector. While tobacco in all forms is "medicine" (poxil), once the leaves are mixed with slaked lime (or other admixtures, such as garlic) it becomes a "magical protector" (metz'tael), often referred to in Mayan-Spanish as sekreto or "secret." Owing to its supernatural potency, in Chamula Tzotzil the protective tobacco mixture is sometimes referred to as "helper" or "assistant" (koltaob-bail), a powerful botanical ally that augments the bearer's strength or "power" ('ip):

Tobacco is called helper" or "assistant” because it has power ('ip), it has strength (pwersa). When we prepare chewing tobacco and put it in the gourd, Our Father 
blesses it. It has power and strength because Our Father used it long ago. Just as you might carry it with you, so he carried it about with him. If you go out walking now, you take it with you, because it has power. Nothing will happen to you as you walk down the trail, even at night. If there is a demon (pukuj), he will not approach, because [the tobacco] you are carrying with you has much stronger power. The demon does not have power like that. If all you have with you is a cigarette, you'll die quickly because a mere cigarette can't defend (-poj) you. But if you have [chewing] tobacco it will drive away the demon, because tobacco has its power. So, if you have it with you, you too will have more power... (CH058-28.VII.03)

The tobacco snuff preparation is said to "defend" (-poj) the user: curing illness, repelling evil forces, blinding witches and earth lords, paralyzing snakes, dissipating storms, protecting from lighting strikes, ransoming captured souls, and conferring an afterlife of rest and repose. Along with candles, incense, and rum, tobacco is one of the primordial foods of the deities, offered to them during fiestas and rituals through proxy ingestion by religious officeholders (see Figures 5a,b). In exchange for these ritual offerings, the deities bestow their benevolent protection upon the community.

Based on its unique protective potential, tobacco has been described as occupying an "intermediate position between deity and amulet" (Page Pliego 2005:143). Holland (1963:107) reports that the Tzotzil of San Andres Larrainzar regard tobacco as a quasi-divine substance that serves as a protector by its mere presence, so long as it is shown respect (ibid.). Breedlove and Laughlin (1993) similarly highlight the protective uses of the tobaccolime mixture, the possession of which confers the ability to "stupefy, paralyze, blind, and drive away adversaries of all kinds." Indeed, these therapeutic and apotropaic uses are at the forefront of contemporary highland Maya tobacco use, and figure prominently in many stories and anecdotes. Summing up its cultural significance, Breedlove and Laughlin conclude: "No other plant... is accorded the magical power, both for good and evil, as that assigned to tobacco. Although this power is focused on chewing tobacco, it is also present in the mere leaf" (1993:242).

The most common method of protecting oneself with tobacco involves administration by rubbing (jaxbil), smearing the moist tobacco-lime preparation over the body, covering the abdomen, limbs, and crown of the head. Such applications are particularly common when traveling at night, or after encountering some dangerous force. People in Chamula say that 
the tobacco-lime mixture "glows" in the dark, producing an intense green-yellow light that repels evil entities such as witches and demons. This glowing light "burns" (-k'ak') these malevolent forces if they try to touch the protected person. A curer explained to me: "Now that you're all covered [with tobacco] you have your light. It's just like electricity-they don't want to touch it because it will give them a shock. [Covered with tobacco] your body is just the same as a live electrical cable, nothing will come to molest you..."

For analytic purposes, the protective uses of tobacco can be arranged into three broad classes: when used to paralyze or neutralize some immediate threat, tobacco is referred to as syaluobil ("that which lowers something"); when used to repel the attack of witches or to protect a person's soul or possessions from the unwanted attention of malevolent forces, tobacco is known as makobil ("that which closes off or blocks"); and when used to protect or "cure" animals or property from supernatural attack, it is called metz'tael ("that which magically protects"). Depending on the informant and context, there is some variation in the application of these terms. For instance, when using tobacco to paralyze a threatening animal, I have heard it referred to as both syaluobil and metz'tael. Similarly, tobacco used to prevent nightmares can be either a syaluobil (if its therapeutic effect is focused on "lowering" or eliminating an existing condition), or makobil (if it is employed primarily as a prophylactic measure to "block off" dream affliction). Each of these apotropaic uses will be discussed in turn:

Yaluobil: “That Which Lowers".-Tobacco's magical ability to incapacitate or neutralize threatening entities or forces that are immediately present (such as an approaching storm, an illness, or a snake, demon, or angry dog encountered on a trail) is referred to as syaluobil ('that which lowers or neutralizes something'). Given the close relationship between chewing tobacco and the deities of earth and sky known as "angels" (anjeletik), tobacco powder gives protection from the dangers posed by these natural forces and the creatures under their control. Indeed, prepared tobacco is widely appreciated for its ability to protect against meteorological threats; when rubbed on the body, it protects one from lightning strikes, and a man pursued by a sickness-causing rainbow can neutralize it by scattering tobacco powder on the ground (Breedlove and Laughlin 1993:243). Similarly, tobacco juice spat toward an approaching storm will divert the winds, driving away the horned serpent (xulub chon) said to ride inside these destructive tempests. Indeed, snakes of all types - said 
to be the "dogs" or assistants of the anjeletik — can be paralyzed by spitting tobacco juice at them; and should one be bitten, a paste of chewing tobacco will neutralize the venom.

Makobil: “That Which Closes or Blocks".-When used as a prophylactic in the prevention of supernatural or ordinary illness, tobacco's ability to "block" (-mak) the affliction is emphasized. For example, tobacco is used in the form of rubs or baths during the final stage of many shamanic curing ceremonies; in such contexts, it is referred to as smakobil chamel ("the thing which closes off or blocks illness"). Ground tobacco and garlic are mixed with cane liquor and rubbed on the head, forearms, and calves during certain curing ceremonies (and after a death in the household) to protect the curer and any observers from being "seized" (-tzak'van) by the sickness. Warm baths of tobacco water (usually sprinkled on the head) also serve to prevent malign forces from returning to afflict the patient during the recovery period.

In Zinacantán, tobacco used to blind witches and their animal companions is referred to as makob jak' chamel ('witch stopper') or makob utz kolo' ('evil stopper') (Breedlove and Laughlin 1993:582). This refers to tobacco's ability to repel or block the witch's entry, distracting the evildoer with its strong odor and causing him "to forget [the victim] completely in both head and heart" (ta sch'ay yo'nton, ta sch'aybe sjol). Indeed, ground tobacco sprinkled in the form of a cross in the doorway and along the walls of the house can also serves to seal it from evil influences, repelling witches and the sicknesses they bring. Tobacco powder rubbed on the body is also used to prevent excessive dreaming, which is linked to pathogenic assaults by witches (see Groark 2017). In the nearby community of San Pedro Chenalhó, a small gourd of tobacco is placed at the head of the bed for protection when someone is ill (Guiteras-Holmes 1961:177).

Should a person fall near a waterhole, river, or cave (many of which are inhabited by "angels" or "earth lords" who snatch the souls of those who fall in the vicinity), shockinduced soul loss can be prevented by promptly rubbing tobacco on the body of the victim. And if, by chance, the person's soul is taken captive "there where the earth has its owner," tobacco powder serves as a medium of exchange in its ransom (see Figure 6). A small quantity of tobacco, along with other "replacement offerings" (k'exolil), is buried at the precise spot where the person fell in exchange for the soul. A Chamula curer explained that tobacco is used in soul collecting rituals because the place where the person fell is "living earth" (kuxul banamil), controlled by an earth deity (anjel) who acts as its "owner." Since 
tobacco is also called anjel, "the two angels talk with one another" and come to an agreement concerning the return of the soul. Another man explained that the strong odor of tobacco serves to distract the earth lord's attention from the captive soul, allowing the curer to retrieve it. Indeed, tobacco is sometimes referred to as makob sat balamil ('closer of the earth's eyes'), referencing its ability to distract the attention - to "close the eyes"-of supernatural beings, thus facilitating the rescue of the captive soul (Breedlove and Laughlin 1993:582). It is interesting to note that Chamula folklore holds that earth lords enjoy only smoking tobacco; the rank odor of chewing tobacco repels them. ${ }^{10}$ During the soul retrieval, all members of the curing party rub tobacco and garlic on their bodies to protect their own souls from being seized in exchange.

Metz'tael: Magical Protection.-Tobacco is also used as a general protective talisman or "secret" (metz'tael, sekreto), shielding the user from the sickening effects of strong emotions in others. In Chamula, parents protect their babies from "hot eye" (k'elsat) — a sickness caused by the benign envy of an admiring person-by tying tobacco, garlic, and chile peppers around the infant's belly before appearing in public. A pregnant woman can also protect her unborn fetus from attack by the "heat" of other infants (an illness known as ti'el, 'a biting'), by wrapping this same tobacco-garlic-pepper talisman around her own belly.

In addition to protecting humans, tobacco is also used to magically protect objects, animals, and crops against damage or molestation, a procedure known as metz'tael ta moy "protection with tobacco." A mixture of tobacco, cane liquor, and garlic is rubbed on the bellies and sides of horses before ritual racing in Chamula center. Common wisdom holds that invidious people send "aire" (ik') into the horses' bellies, causing them to fatigue quickly or stumble. The tobacco rub confers greater "heat" and speed upon the animals, while protecting them from these malign influences. The same mixture, when rubbed on sheep's bellies, serves to eliminate intrusive pathogenic wind or “aire.” In Zinacantán, Breedlove and Laughlin (1993:243) report that tobacco powder and garlic are sometimes sprinkled around cornfields to protect crops from marauding raccoons.

Tobacco is also used when combating a class of stinking supernatural animals known as potzlom. These animals, which often take the form of a small foxlike animal, are understood to be witch transformations or familiars. Should one of these foul creatures approach a house under cover of night, the man of the house must undress and rub his body with tobacco - a process thought to render him invisible - before confronting the animal. If 
the man succeeds in killing it, he throws ground tobacco, garlic, and cane liquor on the corpse to prevent it from reanimating (in this context, tobacco is considered a syaluobil). Vigilantes traditionally used similar protective rubs of tobacco when killing witches, lest the maleficent soul of the evildoer should pass into the body of one of his assailants at the moment of death.

Similar protective applications are also used on objects. In the past, shotguns used in the killing of both witches and their pathogenic animal transformations (potzlometik) were "magically empowered" or "cured" (metz'tabil) by rubbing the barrel with "hot" substances such as tobacco, garlic, and male pubic hair before the attack. During religious ceremonies, ground tobacco is used to protect certain food preparation implements. It is rubbed on cooking pots to protect them from molestation by witches or demons; if not "cured" in this way, the pots may fracture during cooking, spilling their valuable contents into the fire. Tobacco is also applied to tamale pots to ensure that the food turns out well-if neglected, it is said that half of the tamales will come out well-cooked, while the other half remains raw. In Oxchuc, Hayden (2004:10) reports that religious officials rub the tobacco-lime mixture on the neck of ceremonial incense burners in a small household-level ritual involving candles, run, and the burning of incense. Although the author does not provide an explanation for the ritual, similar practices in Oxchuc are designed to bestow protective blessings and transfer the "heat" of tobacco to the object (thereby increasing its ritual potency).

Although tobacco offers great protective potential here on "the face of the earth," it is of even greater importance in the Underworld, where it serves as a sign or indication (senyail) of the deceased person's virtue and adherence to "tradition" during life. Frequent use of tobacco snuff is believed to leave an indelible green stain in the center of the palm, blessing the user with an afterlife of ease. A Chamula man explains the afterworldly benefits of tobacco:

If you know how to eat tobacco, it can be of use to your soul as well. There will already be a sign on your palm (oy xa senyail ta $\boldsymbol{a k}$ 'ob), your hand will be green, really green [right in the center where you place the tobacco]. This is because when you were alive, you ate tobacco. So, if you die or if something happens to you, the tobacco [stain] is there on your palm. You will sit resting in the shade of a tree [in the 
underworld] while the other people work in their fields. If you didn't eat tobacco, you would be given some kind of bad thing [as punishment]... So, it's much better if you know how to eat tobacco, then there is no torment [after death]—you've got the sign there on your palm...

\section{CEREMONIAL USES OF TOBACCO SNUFF}

As discussed above, ritual use of tobacco is currently seen most frequently in the contexts of household-level curing ceremonies and apotropaic rituals (such as protecting onlookers during a curing ceremony, or "closing off" a house from entry by witches). This pattern of domestic use is typical of what Redfield $(1940,1961)$ referred to as the "Little Tradition"- folk rituals of hearth, home, and field, often of a markedly conservative nature. With the arrival of the Spaniards, the elite ideologies and public practices of the "Great Tradition" - typical of urban centers and ceremonial spaces_-were rapidly eliminated. In contrast, the less conspicuous domestic rituals of the Little Tradition were largely unaffected, surviving in isolated Indian communities up to the present.

Today, the only recorded evidence of what might be considered "high ceremonial" Mayan tobacco culture is found in the New Year "Kajwaltik" Ceremony of Santo Tomás Oxchuc, in which thirteen gourds of tobacco-lime snuff are offered on an altar, alongside a "sacred book" (see Thompson 1990:113). This ritual, unique in the highlands, is the only documented case in which tobacco snuff is presented as a formal ritual offering in "official" community-level ceremonial contexts.

Tobacco and Kajwaltik, the "Sacred Book" of Oxchuc. — Every three years, on the 31 st of December, a ceremony takes place in the municipal building of the Tzeltal Maya speaking community of Oxchuc. This ceremony marks the official transfer of power between ritual officials; as the incumbent group finishes their three-year term, ceremonial power and associated symbols of authority are transferred to the incoming officials. Although much of the significance of the ceremony remains obscure, ritual activity is centered on a sacred deerskin-bound volume known as Kajwaltik (“Our Lord”). ${ }^{11}$ 
Throughout the year, the book is stored in a chest in the house of the mayor, but during the ceremony it is placed in the municipal building on an altar table surrounded by thirteen candles, thirteen rosaries, thirteen vessels of atole, and thirteen gourds of tobacco-lime preparation (Thompson 1990:113). On December 31, the sacred batons of office are transferred in front of the book, and for the next three days - the first three days of the New Year - the book is watched over and venerated by the traditional Oxchuc civil and ritual authorities in a ceremony known as "kanan Kajwaltik" ("caring for [the sacred book] 'Our Lord”') (Méndez Girón et al. 2008; see also Redfield and Villa Rojas 1939:114; Megged 1984, 1996:161-162; Esponda Jimeno 1992; Gómez Sánchez et al. 2007).

As Megged (1996:161-162) points out, this ceremony bears striking resemblance to the complex New Year and Year Bearer ceremonies of the Post-Classic Yucatek Maya as described by Bishop Fray Diego de Landa (albeit with a Colonial text replacing the use of the ancient Maya codex books, and a schedule that now accords with the Gregorian calendar instead of the Ancient Maya calendar cycle). Pharo (2014) notes that these PostClassic ceremonies were connected to the election of four officials known as "Chaacs" (Rain Gods), and served not only to mark a new calendrical cycle, but also to initiate more general processes of renewal and restoration. Given the close association between tobacco and the rain-deities of both the ancient and contemporary Maya, the inclusion of thirteen gourds of tobacco in the Oxchuc "changing of office" ceremony suggests as-yet unexplored connections between the New Year ceremony and rituals associated with rain and agricultural fertility. In this regard, it is interesting to note that local oral tradition in Oxchuc holds that the deerskin binding of the sacred "Kajwaltik" book undergoes changes in texture that are understood to presage the quality of the rainy season for the coming year (Rockwell 2005:11; 2006:183-184).

Despite its "high ceremonial" context, the ritual use of tobacco in the Kajvaltik ceremony maintains continuity with common household-level ritual practices throughout the region. In Oxchuc, tobacco is still placed on family altars during family-level ceremonies, and it is often blessed by ritual officeholders before use at fiestas (see Figure 5a,b). In Chamula and Tenejapa, tobacco-filled gourds are sometimes stored on or under 
the household altar, a placement that indicates tobacco's status as a first-order ritual substance, a food fit for gods.

\section{COSMOLOGICAL ASSOCIATIONS OF TOBACCO AND GOURD}

To fully appreciate tobacco's significance as a quasi-supernatural therapeutic and protective agent, we must understand its place within local cosmology and mythology, both past and present. While ancient Maya cosmological beliefs surrounding tobacco remain obscure, recent investigations shed some light on pre-Columbian tobacco ideology and practice.

Based on extensive epigraphic and iconographic research, it appears that the Classic Maya "Old God L" (most famously depicted as an old man smoking a large cigar in the Temple of the Foliated Cross in Palenque) represents "the very personification of tobacco itself in all of its forms" (Carlson 2007a,b; see also Miller and Taube 1993:112, 147, 169; Kerr and Kerr 2005) Based on epigraphic evidence, Carlson suggests that God L was referred to as both Mahy ('tobacco') and probably $\boldsymbol{C h}$ 'ul Mahy ("Holy Tobacco" or "Holy Medicine"). This deity represents the "First Shaman" or "First Priest," and was the principal deity associated with medicine and curing. For the purposes of this article, it is significant that this deity is often depicted facing God K, a deity related to the Mayan Storm God complex (Kerr and Kerr 2005).

This association between tobacco and deities of storm and sky can still be found in fragments of contemporary highland Maya cosmology. As mentioned, tobacco snuff is referred to as "Elder Brother" (bankilal) in many Tzeltal and Tzotzil Maya communities. This name indexes local cosmological beliefs in which Tobacco is explicitly identified as the elder brother of Thunderbolt (chauk, anjel). It is said that Elder Brother Tobacco scolded Younger Brother Thunderbolt for striking people, and that tobacco now serves to protect people from meteorological disturbances such as destructive 'thieving winds" (j'elek' $\boldsymbol{i} \boldsymbol{k}$ '), lightning (chauk), and sickness-giving rainbows (vaknabal). A man from Chamula explained the relationship as follows:

Thunderbolt (chauk, anjel) is younger brother (itz'inal) of tobacco. Tobacco has power over storms because he is the older brother (bankilal) of lightning and thunder. 
If the wind and thunderbolts come, tobacco dissipates them. The two talk togetherThunderbolt up above and Tobacco here [on the earth]. They talk with each other and the storm calms. Since tobacco is the older brother, he has more power. He diminishes the power of his younger brother, thunder and lightning. That is why [tobacco] is called "Elder Brother" (bankilal)... (CH085-01.V.06)

Based on similar ethnographic data from across the region, Carlson speculates that Old God L ("Holy Tobacco") and God K ("Smoking Lightning Axe") are related to one another as elder and junior brother, respectively.

As mentioned, in Chamula Tzotzil the favored name for prepared tobacco snuff is anjel ("angel"). This term references the same network of associations as the "older brother" appellation, emphasizing the connection between tobacco and a class of deities of earth and sky also known as "angels." Among both Tzeltal and Tzotzil speakers, the term anjel refers principally to thunder and lightning, as well as tobacco. The name also refers to the various "earth lords" (yajval vitz) that inhabit local landforms (such as waterholes, mountains, and caves), all of whom are closely associated with the production of both nourishing rains and destructive winds (cf. Mendelson 1967; Thompson 1970:267-270). Owing to its kin relation as "elder brother" to thunderbolt, tobacco exercises control over these "angels" and the elemental forces with which they are associated. This senior-junior (bankilal-itz'inal) relationship is drawn on to explain tobacco's ability to defend against dangers posed by these potentially malevolent forces of earth and sky. In Chamula, tobacco can be thrown or spit toward an approaching storm to prevent destructive winds. Similarly, in San Pedro Chenalhó, people used to put powdered tobacco in their cheeks to reduce the intensity of thunder and lightning (Guiteras-Holmes 1961:177; cited in Stoller and Stross 2013).

Köhler's (1995) ethnohistoric work on the relationship between rain gods, earth lords, and "angels" illuminates some of the cosmological underpinnings of highland Maya tobacco belief. During the Colonial Period, tobacco (anjel) appears to have become associated with Saint Michael the Archangel (San Miguel Arcángel), the most senior angel in God's army, and the leader of the heavenly forces that triumphed over the rebel angels led by "the dragon" (identified with Satan). In the Yucatan, the name canjel refers to San Miguel Arcángel, as well as various elements and phenomena associated with the rain gods, such as thunder, lightning, and storms (Redfield and Villa Rojas 1934:116; cited in Köhler 1995:123). Köhler argues that canjel derives from a contracted form of arcángel, the title of the supreme rain 
god San Miguel Arcángel, the most "senior" (or bankilal) of the local chaacs, or rain gods (Köhler 1995:123). Here we find a plausible historical connection explaining the origin of both the "Senior/Elder brother" appellation, as well as the close association between tobacco and "angelic" protective power. Drawing on the work of Lehmann (1949), Köhler points out that the story of San Miguel Arcángel played an important pedagogical role in the evangelization efforts of early missionaries, who emphasized that many of the beings worshipped by the Maya as gods (for instance, various "earth deities") were in fact the fallen angels defeated by San Miguel and banished from Heaven (Köhler 1995:125).

This evangelical account of a battle in the sky between warring angelic armies connected the Christian "angels" to the thunderous rain gods of the ancient Maya, and the iconographic representations of San Miguel brandishing a flaming sword while standing atop a defeated serpent or "dragon" readily associated him with the forces of lightning and thunder, as well as snakes (ibid.). As discussed, this association persists in contemporary highland Maya beliefs linking tobacco to protection from meteorological disturbances such as lightning strikes, hailstorms, destructive winds, serpents, and demonic forces of all kinds.

Indeed, tobacco has been deeply integrated into the syncretic Christian cosmology held by traditional Mayan Catholics. ${ }^{12}$ As a "traditionalist" man from Chamula explained to me, the protective power of tobacco was recognized during the First Creation by Our Father in Heaven (jotitk ta vinajel) the Sun-Christ deity, the primary protector of humanity and the first person to plant and use tobacco:

A long time ago, Our Father walked like a real person-like us, he walked the earth. And tobacco, well he carried it with him as he walked about. That's why tobacco remains on earth and continues to serve the people. You know why? Because Our Father carried it with him, he had his tobacco a long time ago. He chewed tobacco and used it whenever he went walking about... That's the way they say it was long ago with Our Father. He always carried his "assistant" (koltaob-bail), he had a helper to augment his own power... (CH085-01.V.06)

Tobacco thus served as a powerful ally even during the First Creation, protecting the Sun deity himself during his travels on the face of the earth. Contemporary highland Maya attribute significant protective powers not only to the tobacco plant, but also to the gourd in 
which tobacco snuff is stored. Indeed, as we will discuss below, the gourd itself has come to possess quasi-talismanic properties, protecting the owner against a wide range of threats.

Talismanic Properties of the Tobacco Gourd.-The tobacco gourd, like the tobacco plant itself, is closely linked to protective powers, particularly the ability to safeguard the owner during travels away from home. Indeed, tobacco-filled gourds continue to serve as general protective talismans, and are often stored in the house. Several people I spoke to explained that the gourd gains its strength from the constant absorption of concentrated tobacco juice, which gradually infuses the container with the same power as the plant.

Like tobacco, the gourd is said to "glow" or emit light when dangerous forces draw near or when its owner needs assistance. In a tale from the Tzotzil community of Zinacantán reported by Breedlove and Laughlin (1993:242), men working on a lowland coffee plantation slept with tobacco gourds next to their heads. When the evil-intentioned plantation owner looked in upon the workers, he saw flames dancing on the ground next to the gourds and left them unmolested. Describing the Tzeltal community of Tenejapa, Maffi (1996: 42; footnote 22) recounts a widely-held belief relating to the protective role of the tobacco gourds: “... should one become lost somewhere along a path away from home, especially while drunk - and maybe even pass out and fall in a ditch — the small gourd would begin to shine brightly, revealing one's location to rescuers. Older Tenejapans... still [swear] to having witnessed this phenomenon." The author reports that men always used to carry tobacco snuff gourds, but that "this habit is now waning" (ibid.) However, during a fiesta I attended in the community in 2003, I made an informal survey of the authorities and religious office holders celebrating in the church, and found that most men carried a small gourd of tobacco in their shoulder bag. ${ }^{13}$

Although many of the underlying cosmological associations have been lost, the tobacco gourd appears to have been rich with symbolic import. A Chamula folktale I collected in 2003 recounts how the Sun-Christ deity's tobacco gourd transformed into Hummingbird at the end of the First Creation, explaining both the origin of the hummingbird as well as its unique dietary preferences:

Our Father's tobacco had its container [its gourd] (yavil moy). When he ceased to walk the earth long ago, his tobacco gourd was thrown aside and fell into disuse. It felt sad there where it was left, so it transformed into a bird, it became a hummingbird 
(tz'unun). Now that hummingbird... he didn't know how to eat food; he just sucks the juice of flowers. This is because nothing but [fresh] tobacco was placed in the gourd [when Our Father carried it], nothing else. That's why it turned into a bird, into a hummingbird. That's why the hummingbird is called 'Our Father's tobacco gourd' (stzual smoy jtotik). ${ }^{14}$ The tobacco gourd sprouted wings, spouted feathers. He began to flutter about in the air. So, that tobacco gourd, it has a soul, its soul is Hummingbird... (CH058-28.VII.03)

After relating this account, the narrator explained that the primordial link between the tobacco gourd and the hummingbird is preserved as a "sign" in the form of the gourd: the rounded gourd (tzu) is the body, the pointed tip (neil) is its tail, and the stopper (suk stzual moy) and retaining string (yak'il) form the head and beak.

Indeed, as this myth fragment indicates, the tobacco gourd is symbolically linked to the origin of the hummingbird, and seems to share something of its essence (or vice versa). As the final line of this story reveals, the soul of the tobacco gourd is none other than Hummingbird, messenger of the Sun and protective animal companion of warriors throughout Mesoamerica.

Recinos (1961[1952]:105-105) points out that Hummingbird was connected to the ancestral creator deities of the Popol Vuh, acting as their animal soul companion, the "guardian and protector of the people and their souls..." (cited in Page Pliego 2005:146). Similarly, Guiteras Holmes (1961:248) reports that in the Tzotzil community of San Pedro Chenalhó Hummingbird is considered to be one of the most powerful animal souls, possessed only by the totilme'iletik ("father-mothers"), a hidden cabal of supernaturally powerful men who protect the community from illness and other invasive threats. Hummingbird is said to protect people's animal souls from predation by Jaguar, who will kill and consume them should they find themselves unprotected (ibid: 134). In this regard, it is interesting to note that Brent Berlin recorded a Tenejapa Tzeltal tale in which a man is saved from a jaguar by the protective power of his tobacco gourd (personal communication, July 2008). In addition, Hunt (1977) has established a close connection between Hummingbird and the Sun, an association reflected in the aforementioned myth from Chamula, in which the tobacco gourd serves as a protective "helper" to the young Christ deity, before his death and resurrection as the Sun. 
Additional myths from Guatemala emphasize this Sun-Hummingbird-Tobacco connection. A Mopan Maya myth reported by Thompson (1970/1990:364) describes an adventure of the young Sun deity who, while attempting to woo a young girl who would later become the Moon, slipped and fell in front of her. As she laughed at him, he transformed into a hummingbird and darted back and forth between the flowers of a tobacco plant, drinking their nectar. After the girl's father killed the hummingbird with a blowgun dart, the girl took the dead hummingbird into her room where it revived, and they fled together to become the Sun and the Moon. A cognate myth collected among the Kakchiquel Maya indicates that at night the Sun transformed into a hummingbird to visit his lover-the future Moon - in a disguised form that would not be noticed by her father (ibid:365). In a Kekchi version of this same story, the young Sun deity is explicitly identified as Xbalanque-Jaguar Sun - one of the hero twins of the Popol Vuh (ibid:364).

Despite the gaps and inconsistencies in these diverse accounts, a close association appears to exist among Tobacco, Hummingbird, and various progenitor deities, be they God L of the Ancient Maya, the Hero Twins of the Popol Vuh, or the Sun and Moon of contemporary Maya communities. As this discussion demonstrates, echoes of these ancient stories can still be found in contemporary highland Maya communities, where tobacco continues to be recognized as both a "primordial medicine" and powerful "botanical ally" with dominion over deities of earth and sky.

\section{CHANGES IN TRADITIONAL TOBACCO USE PATTERNS}

Despite the complex and multifaceted tradition of tobacco use that has been maintained in the highlands since the time of the ancient Maya, the practices described in this paper are disappearing. In closing, I offer some observations on the changing nature of tobacco culture in the highlands of Chiapas. Although tobacco continues to be used, the contours of "traditional" use have shifted, becoming at once more limited and more closely associated with orthodox religious belief and practice.

Vignette 1.-On a humid afternoon in 2005, during a fieldtrip to the Maya archaeological site of Palenque, I sat outside the entrance to the ruins with a Tzotzil Maya friend, resting in the shade. Two young girls - second-generation colonists from my friend's natal hamlet in the 
Tzotzil-speaking community of San Juan Chamula — sat down and began chatting with us. During a lull in the conversation, I casually poured some tobacco snuff into my palm and tossed it into my mouth. The girls watched quietly with a puzzled expression, looked at each other, then asked me what I had just eaten. My Maya companion was stunned. "You don't know what that is?" he asked, "You don't know how to 'eat' tobacco here?" When the girls replied that they had never seen anyone do this before, he told them, "That there is tobacco (moy), we call it 'angel' (anjel) in Chamula...” After a moment of silence, he asked again, "You really don't know how to eat tobacco here...?" Although this exchange took place in the Chiapas lowlands with the children of expatriated Tzotzil Maya colonists, similar processes of change and loss of ethnobotanical knowledge are occurring in the highlands as well. Despite its millennia-deep history, Maya tobacco culture is transforming - and in many cases, being lost — at an alarming rate.

Vignette 2.-During fieldwork, I made a habit of carrying tobacco with me wherever I went. I always brought it to fiestas and offered it to the ritual officials and their retinues. Invariably, they would accept the proffered tobacco with enthusiasm, asking me where it came from, and where I "learned to eat" tobacco. One young man, observing my habit of chewing tobacco in social settings, rebuked me, saying: "We don't use tobacco like that. For us, it's like a 'secret' (ja' $\boldsymbol{k}$ 'u cha'al jun sekreto), we just use it for protection, for curing. You chew it all the time, it's just another vice, like smoking..."

This comment highlights a split in contemporary highland Maya tobacco use: the native tobacco-lime snuff preparation has become increasingly sacralized and is now almost exclusively associated with ritual, medicinal, and protective uses, while its more secular and social functions have been replaced by commercial cigarettes (sikarol). ${ }^{15}$ The rapid spread of evangelical Protestantism in the highlands has further contributed to decline in both knowledge and use of traditional tobacco. The plant is closely linked to the practice of traditional curers, a group that has been rejected by Protestant converts as morally suspect and evil. Thus, many of the powerful ritual substances associated with traditional curingparticularly those with an intoxicating effect, such as tobacco and cane liquor-have also been rejected as corrupt and spiritually threatening. 


\section{CONCLUSIONS}

Throughout the Maya region, tobacco is regarded as a supernaturally powerful plant. Both ancient and modern Maya employed the plant (in various forms) as an intoxicant, a stimulant, a medicine, and a potent magical agent - a general-purpose "botanical ally" or protector. Traditional tobacco use continues to play an important role in the therapeutic, religious, and ritual life of many contemporary Tzeltal and Tzotzil Maya in the Chiapas Highlands of southern Mexico. However, despite the plant's manifest cultural importance, to date there has been no focused ethnographic study of its uses. Accordingly, my primary goal for this chapter was to record "traditional" Highland Maya tobacco culture, documenting Nicotiana preparation, use, and associated beliefs while they are still available for study in the form of a living ethnobotanical tradition. Following an overview of highland Maya tobacco ethnotaxonomy and nomenclature, I describe highland Maya tobacco preparation, exploring its use in therapeutic and apotropaic contexts. Integrating ethnographic interviews conducted in the Tzotzil-speaking community of San Juan Chamula with the broader ethnographic and ethnohistoric record for the region, I present an overview of the cosmological and mythological significance of tobacco within the highland Maya worldview. Owing to both its chemical potency and quasi-magical power, both Tzeltal and Tzotzil Maya attribute to the plant an ability to overpower a wide range of illnesses and supernatural threats. Indeed, controlled nicotine ingestion — particularly in the form of oral snuffgenerates a range of positive psychological and physiological effects, supporting the local belief that tobacco is, in fact, one of the primordial "powerful substances" in the pharmacopoeia of the highland Maya. 


\section{FIGURES}



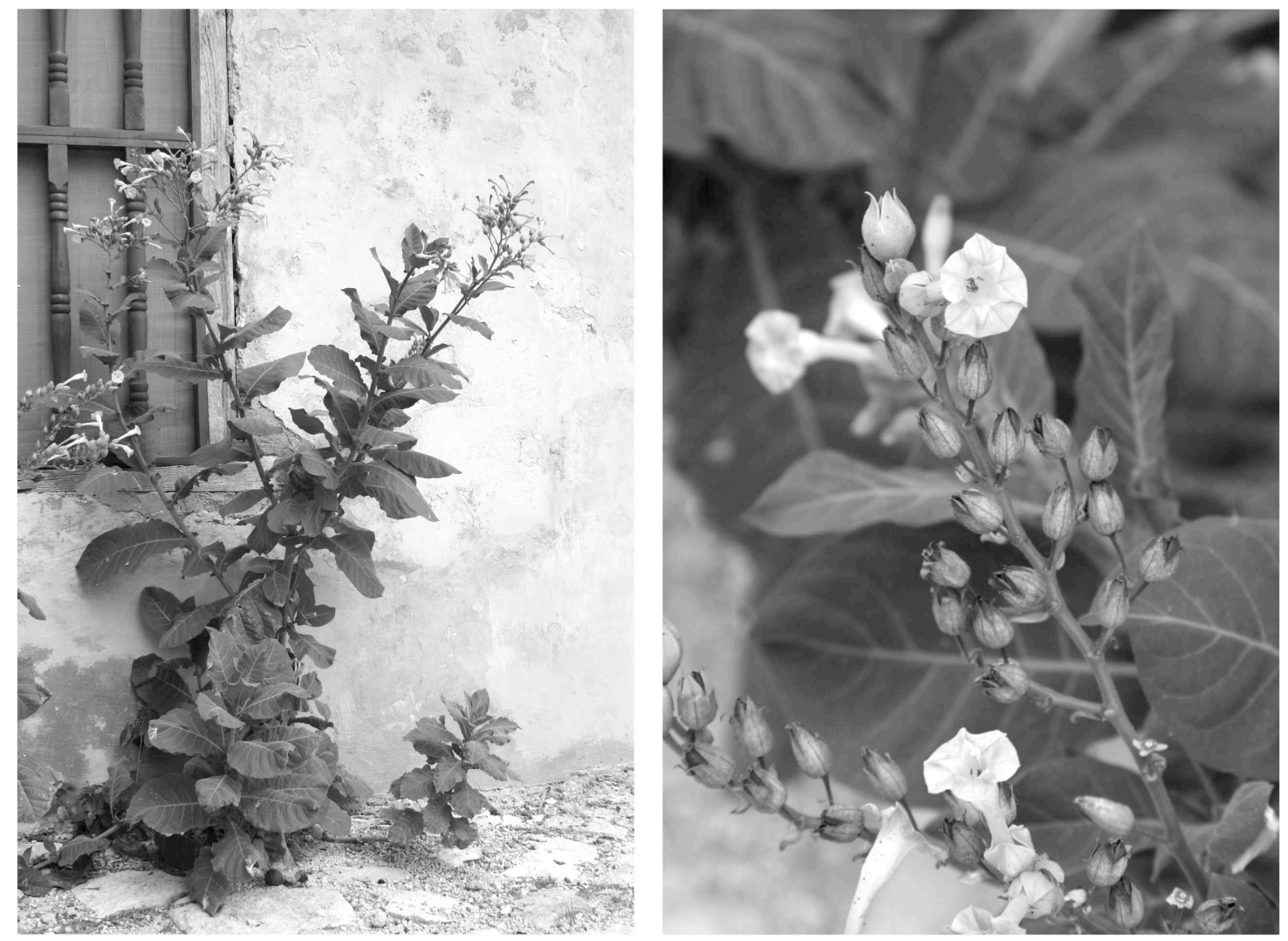

Figure 1-Tobacco Plant (Nicotiana tabacum L.) and inflorescence ( Kevin P. Groark)
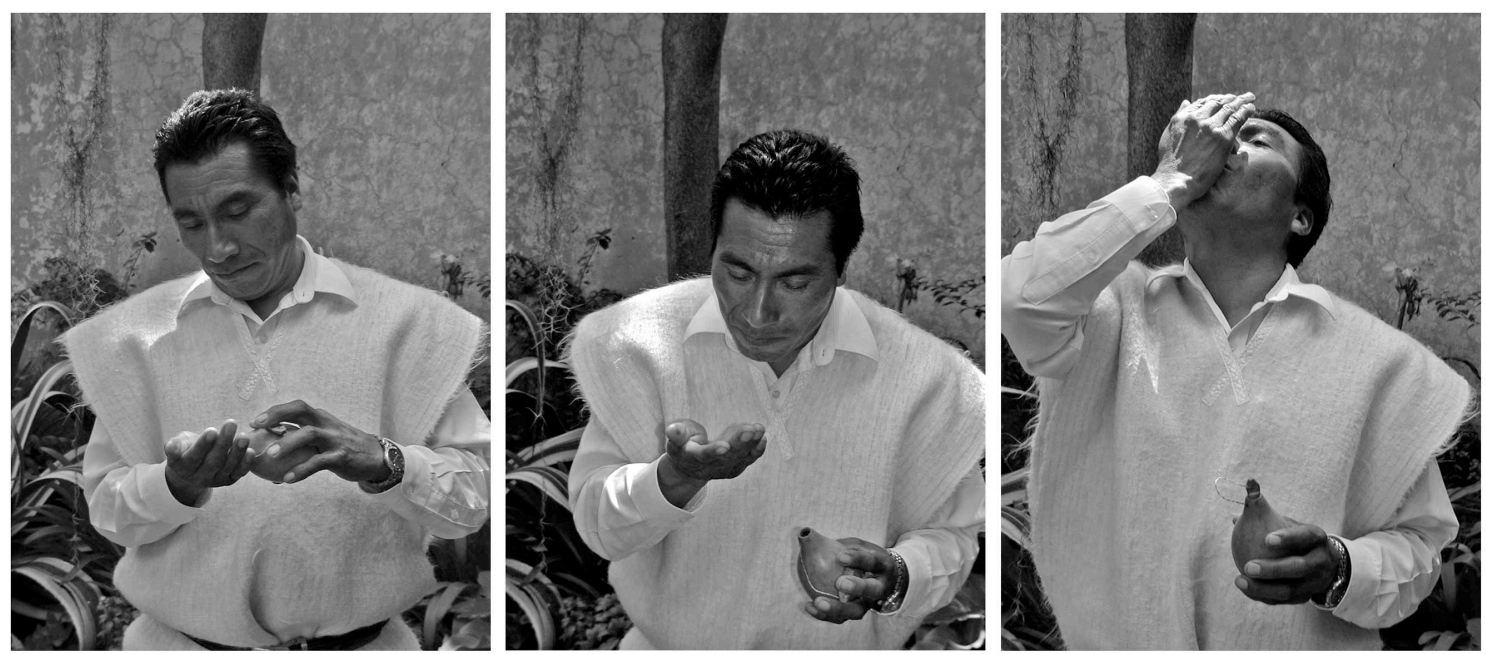

Figure 2- Chamula man using tobacco snuff (C Kevin P. Groark) 

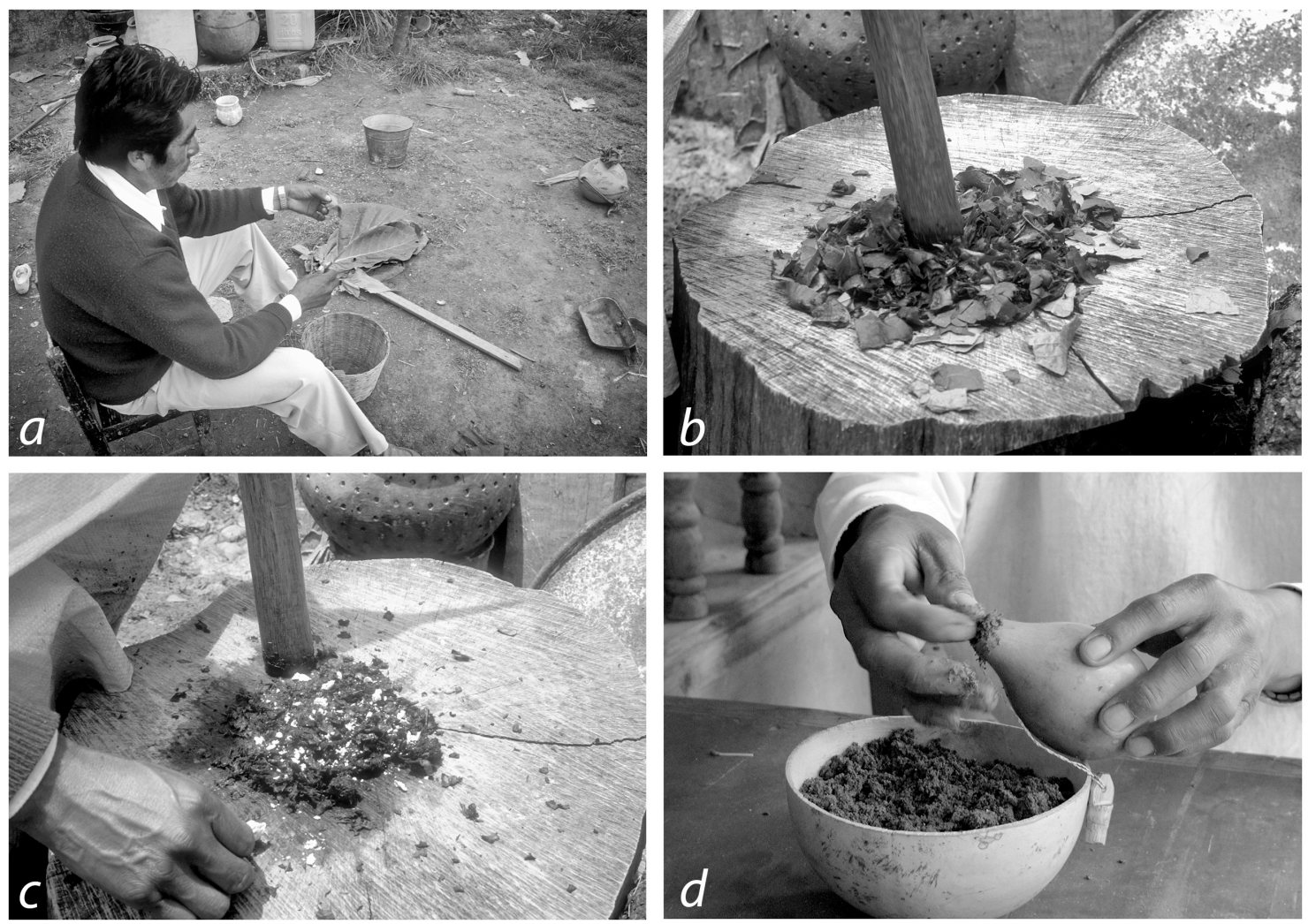

Figure 3- Preparing tobacco snuff from fresh Nicotiana leaves, San Juan Chamula 1998 (C) Kevin P. Groark) 

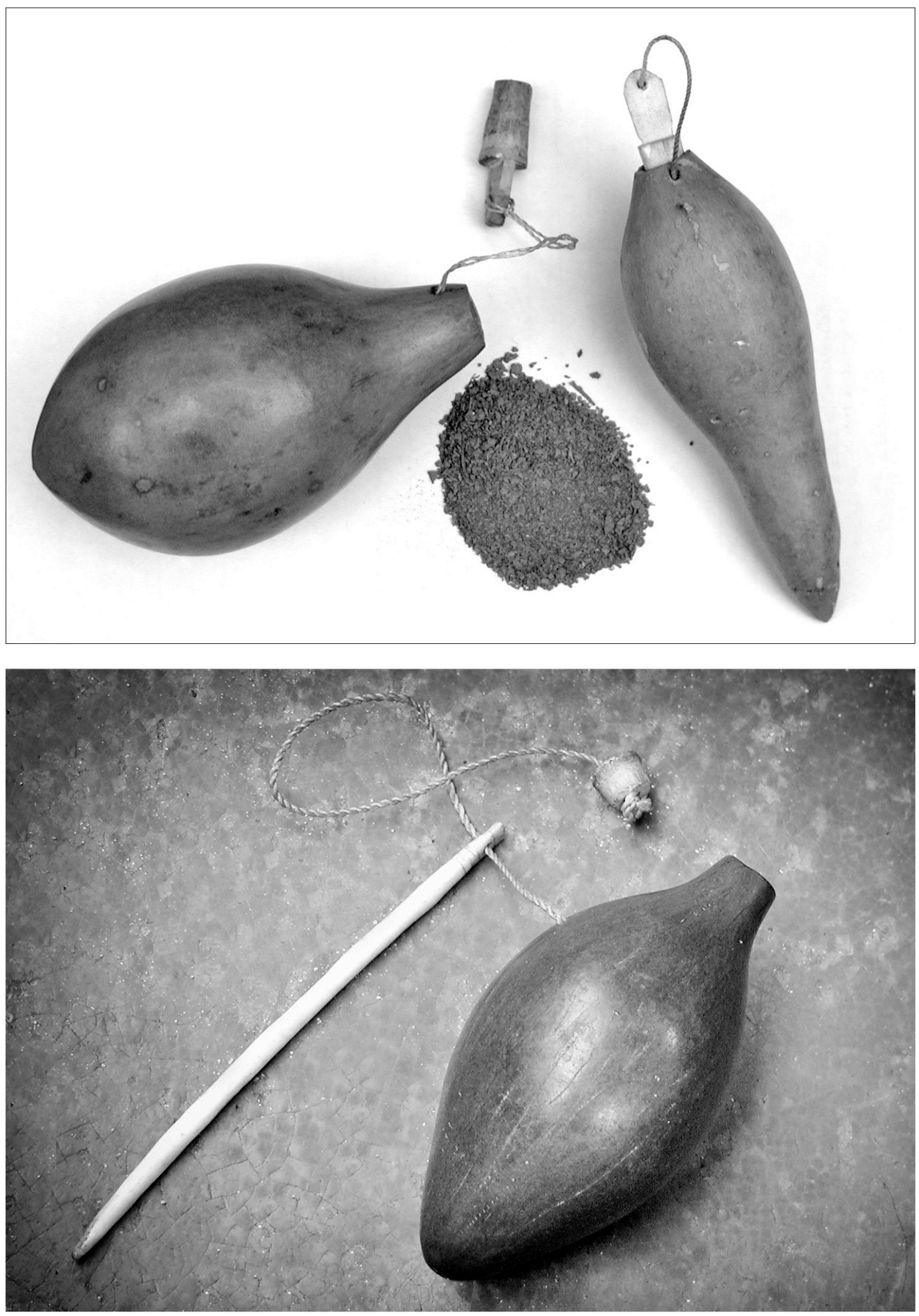

Figure 4- Tobacco gourds, prepared tobacco, and bone dipper ("female" and "male" forms, top left and right) (@ Kevin P. Groark) 

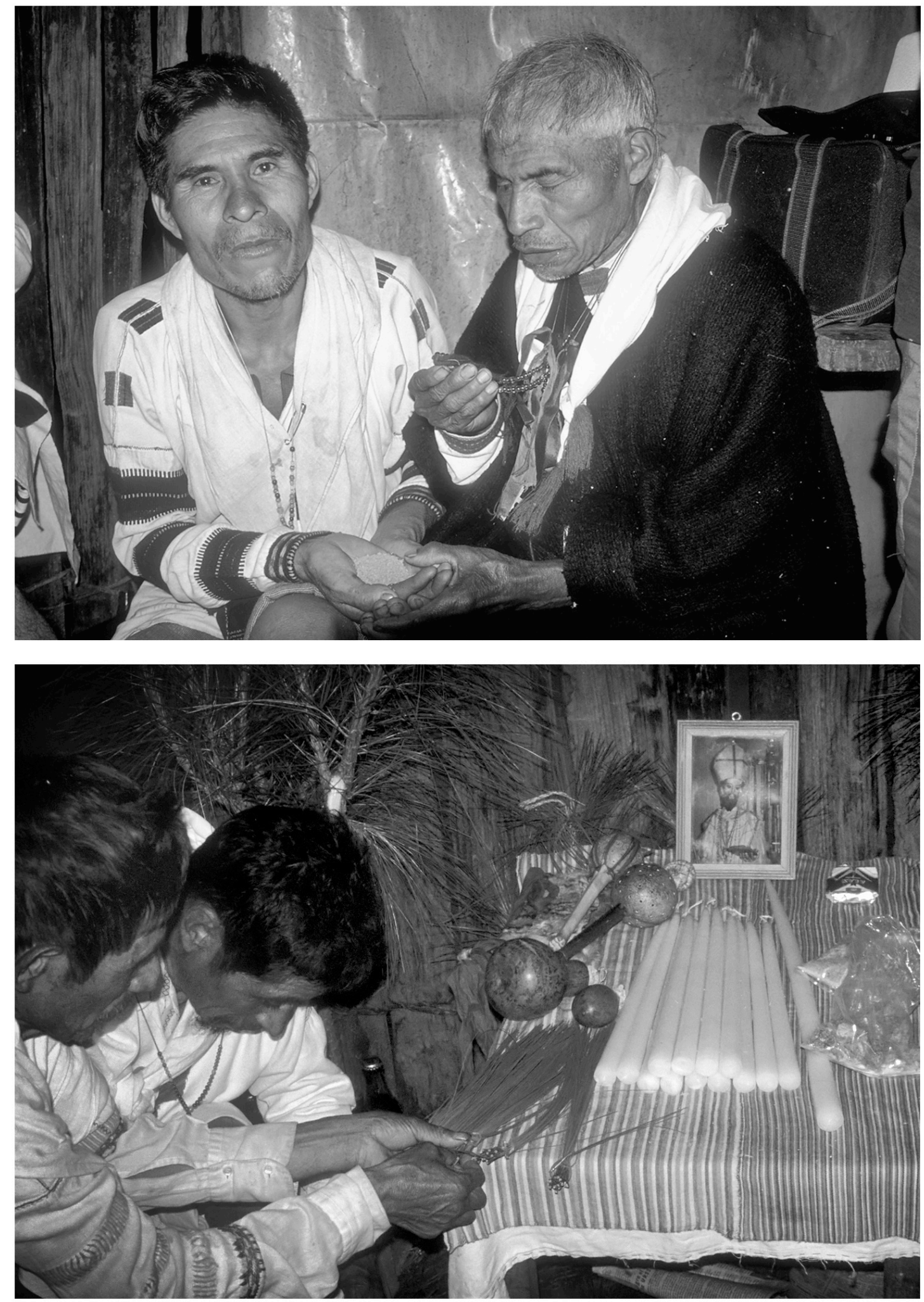

Figure 5- Religious officials blessing tobacco with rosary and placing gourds on altar Santo Tomás Oxchuc, 1991 (C Kevin P. Groark) 


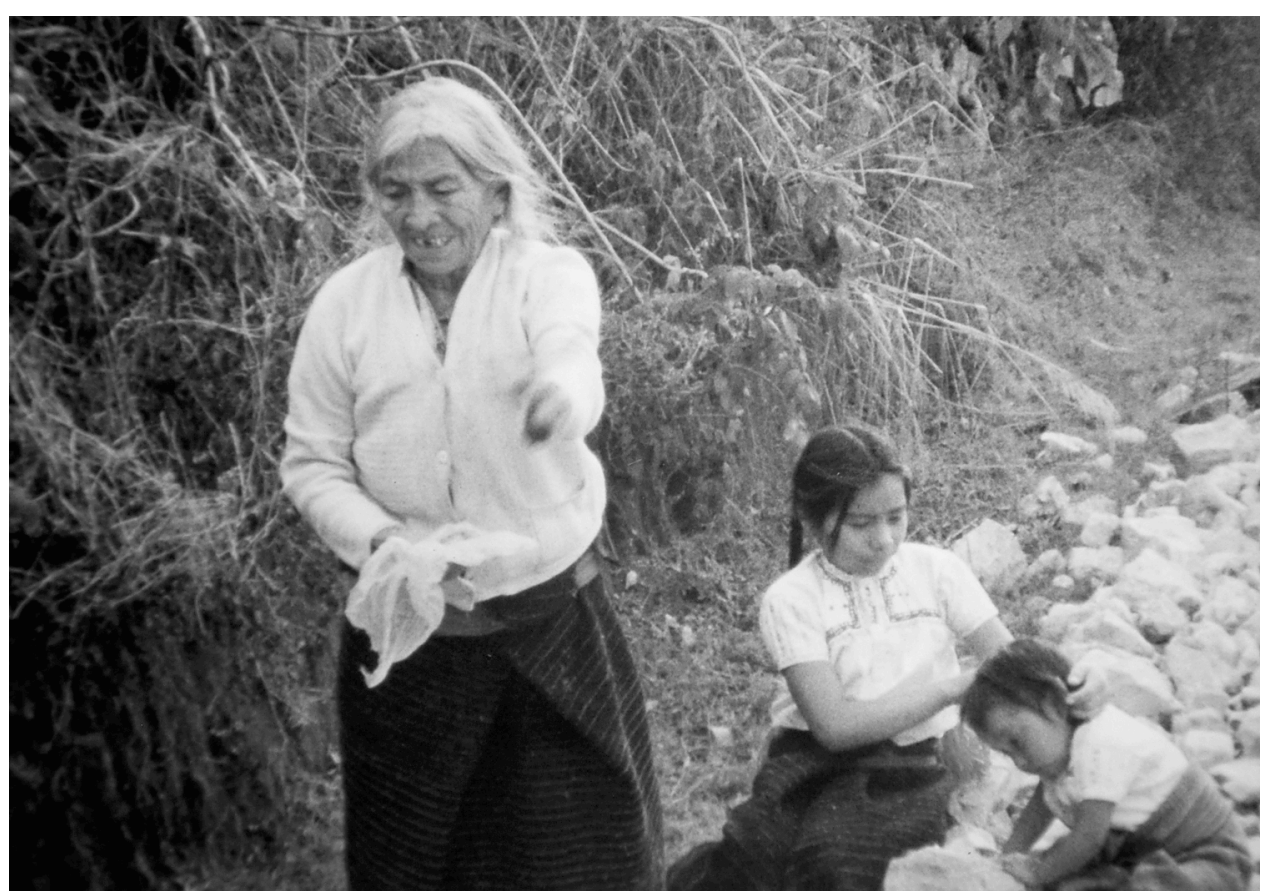

Figure 6- Female curer offering tobacco powder to Earth Lord during curing ceremony for pediatric soul loss, San Juan Chamula 1998 (@ Kevin P. Groark) 


\title{
ENDNOTES
}

\begin{abstract}
${ }^{1}$ The current chapter is an expanded and revised version of a paper that was originally published by the Journal of Ethnobiology under the title "Angel in the Gourd: Ritual, Therapeutic, and Protective Uses of Tobacco (Nicotiana tabacum) among the Tzeltal and Tzotzil Maya of Chiapas, Mexico" (Groark 2010). [Reprinted by permission from Journal of Ethnobiology, Volume 30(1), CCopyright 2010, Society of Ethnobiology]. Ethnographic data presented in this chapter were collected between 1992 and 2008 in the Tzotzil Maya community of San Juan Chamula, with supplementary data and observations from the Tzeltal Maya communities of Santo Tomás Oxchuc and Tenejapa. Unless otherwise noted, all native language terms are in the Chamula dialect of Tzotzil, and all interview excerpts were translated from Tzotzil Maya by the author. Field research was supported at various stages by the National Science Foundation, ISOP-Ford Foundation, Tinker Foundation, the Department of Anthropology at the University of California Los Angeles, and the Division of Occupational Science and Occupational Therapy at the University of Southern California.
\end{abstract}

${ }^{2}$ Throughout this article, I employ the following technical convention when discussing the plant and its cultural uses: the genus name Nicotiana is used when referring to the plant, while the term tobacco will be used when referring to prepared forms of the plant (such as chews, snuffs, or smoked forms).

3 Despite this, it is believed that too many young plants growing around the house can threaten the safety of the domestic space; the collective "heat" of the tobacco plants is said to bring starvation or sickness to the house (Breedlove and Laughlin 1993:242).

${ }^{4}$ Per Wilbert (1987:137), oral administration—in which little or no tobacco juice is expectorated-maximizes enteric absorption of nicotine through the buccal cavity, the stomach, as well as the small and large intestine (see D’Orlando and Fox 2004). Indeed, nicotine absorption from tobacco quids is two to three times greater than that obtained from smoked tobaccos (Benowitz et al. 1988). Absorption rates depend on the size of the quid, fineness of grinding, the time the quid is retained, its relative movement within the mouth, and the presence of alkalizing agents; but under optimal conditions, total absorption is 
possible (Wilbert 1987:137.). Since the nicotine alkaloid is miscible in salivary secretions, rapid diffusion across the epithelium and vascular barriers provide ready access to the heart and circulatory system, thereby elevating blood levels of nicotine (ibid:137-138).

${ }^{5}$ The use of alkalizing agents (such as slaked lime) in the preparation and/or administration of tobacco raises $\mathrm{pH}$ to levels that maximize the bioavailability of free nicotine (Henningfield et al. 1995; Tomar and Henningfield 1997; Renner et al. 2005). Unprotonated or free-base nicotine is rapidly absorbed through the mucosal membranes in the oral cavity, resulting in levels of serum nicotine 2 to 3 times higher than that produced by smoked tobacco (Benowitz et al. 1988). Alkaline substances increase salivation, thereby creating an oral microenvironment that accelerates and intensifies the action of the drug (Wilbert 1988:138). ${ }^{5}$ This practice catalyzes the chemical potential of the tobacco leaf, effectively augmenting its potency and bioactivity.

${ }^{6}$ Although many people mentioned the use of admixtures, in more than 25 years of research in the region, I have never seen them employed in tobacco preparation.

${ }^{7}$ Suitable specimens are sold in regional markets, but they are quite expensive; a typical container with no stopper costs about $\$ 10$ pesos (which, in the 1990 's, was roughly $20 \%$ of a man's daily wage). Breedlove and Laughlin (1993:135) describe the labor-intensive process involved in preparing dried gourds for sale: "[First, ] the end of the gourd is broken and the gourd is placed on a fire, if still green, to remove the outer rind. Then it is buried for two days. When it is dug up, the pulp is removed and the inner surface is scraped and rinsed. The gourd is set in the sun for 2-3 days to dry. Then, the outer surface is scraped with a knife." This lengthy preparation process, combined with the difficulty of procuring gourds with no insect holes or unsightly blemishes, accounts for their high cost.

${ }^{8}$ As Brett (1994) has pointed out, strong medicines often have a range of adverse effects on the body of the person who consumes them; as this struggle between medicine and illness unfolds, it is expected that the patient may feel worse before improving. Indeed, excessive tobacco ingestion (especially in liquid forms) can lead to dilation of the pupils, cold sweats, nausea, stomach pain, and vomiting. 
${ }^{9}$ In Chamula oneirocritic theory, tobacco and madness are closely connected - if a person accepts and consumes proffered tobacco in a dream, their head will feel "drunk" the next day (xyak'ub sjol), and they may be stricken with aggressive madness (chuvajib sjol) that manifests as unjustified anger towards family and friends. The association between tobacco and madness appears to derive from the fact that both tobacco and madness make the individual feel "drunk" (-yakub), and the dream ingestion of intoxicating tobacco augurs the onset of a similar aggressive "drunkenness" or disorientation in waking life.

${ }^{10}$ Reflecting this belief, an archaic euphemistic name for a local snail species is "the angel's smoking tobacco vessel" (yav smoy anjel / yav sikol anjel), a reference to the snail shell, which the "angels" and earth lords use as their pipe (skachimpá anjel, "angel's pipe"). These are now little-known expressions, and typical only of older speakers who use them for humorous effect. In the Yucatán, earth lords and rain deities are said to be extremely fond of smoking tobacco, and cigars form a central element in rain ceremonies, in which they serve to prevent "bad winds" from accompanying the rains (Gabriel 2007:172-173).

${ }^{11}$ Although I was never shown the book, those who have examined it report that it consists of a set of Colonial Royal Ordinances delivered in 1674 by the visiting Guatemalan judge Jacinto Roldán de la Cueva (Esponda Jimeno 1992). Contemporary Oxchuqueros are unaware of the actual provenance of the tome as well as its contents, regarding it simply as a "sacred book" linked to the continued well-being of the municipality.

${ }^{12}$ An old Tzeltal woman from Chanal (which separated from Oxchuc about 150 years ago) commented that, in Oxchuc, tobacco is linked to Santo Tomás, the patron saint of the community. In fact, she claimed that the common metaphorical name for tobacco [bankilal, "elder brother"] referred directly to this saint).

${ }^{13}$ The diversity of forms used in Tenejapa was impressive; while many men were using the traditional "male" and "female" forms of Lagenaria siceraria, a significant number were also carrying small, tight-waisted, "hourglass-shaped" gourds, often attached to thin woven straps and hidden away in their shoulder bags. 
${ }^{14}$ Chamulas recognize two varieties of hummingbird, bik'ital tzu ("little tobacco gourd") and muk'ta tzu ("big tobacco gourd") (Gossen 2002:98). The common name for hummingbird is tz'unun.

${ }^{15}$ Today, the daily use of tobacco snuff is rare. Although still seen among some old men (as well as people living in distant and isolated communities), traditional tobacco use is now most frequently encountered in ceremonial, religious, protective, and therapeutic contexts. Despite the plant's ritual associations and close association with curing, anecdotal data suggests that such restricted use was not always the rule. When asked about less formal uses of tobacco, Chamula informants recalled "old men" they knew who were "always walking around eating tobacco," and humorously observed that these men could be readily identified by the tobacco stains on their left palms. The ubiquity of tobacco gourds in the shoulder bags of highland Maya men further attests to its past use in everyday contexts. When the profound physiological effects of nicotine are considered, "secular" uses of tobacco should come as no surprise (and given the potent addictive potential of nicotine, some degree of habitual use should be expected). 


\section{REFERENCES CITED}

Badio, B. and Daly, J. 1994. Epibatidine, a potent analgesic and nicotinic agonist. Molecular Pharmacology 45:563-568.

Benowitz, N.L., Porchet, H. and Jacob, P. 1990. Pharmacokinetics, metabolism, and pharmacodynamics of nicotine Pp. 112-157 in Nicotine Psychopharmacology:

Molecular, Cellular, and Behavioural Aspects (S. Wonnacott, M.A.H. Russell, and I.P. Stolerman, eds.). Oxford University Press, Oxford.

Benowitz, N.L., Porchet, H., Sheiner, L. \& Jacob, P., III. 1988. Nicotine absorption and cardiovascular effects with smokeless tobacco use: comparison with cigarettes and nicotine gum. Clinical Pharmacology \& Therapeutics 44:23-28

Berlin, E.A. and Brent B. 1996. Medical Ethnobiology of the Highland Maya of Chiapas, Mexico: The Gastrointestinal Diseases. Princeton University Press, Princeton.

Berlin, B., E.A. Berlin, D.E. Breedlove, T. Duncan, V.M. Jara Astorga, and Robert M. Laughlin. 1990. La Herbolaria Médica Tzeltal-Tzotzil en los Altos de Chiapas: un ensayo preliminar sobre las cincuenta especias botánicas de uso más frecuente. Gobierno del Estado de Chiapas (Consejo Estatal de Fomento a la Investigación y Difusión de la Cultura / DIF-Chiapas / Instituto Chiapaneco de Cultura), Tuxtla Gutiérrez, Chiapas, México.

Breedlove, D.E. and R. M. Laughlin. 1993. The Flowering of Man: A Tzotzil Botany of Zinacantán (2 Vols). Smithsonian Institution Press, Washington, D.C.

Brett, J.A. 1994. Medicinal plant selection criteria among the Tzeltal Maya of highland Chiapas, Mexico. Ph.D. Dissertation (Anthropology), University of California, Berkeley. 
Carlson, J.B. 2007a. Tobacco in enema? \& "Maya flasks and miniature vessels". Aztlan listserv posting on FAMSI Website, July 8, 2007. Available at: http://www.famsi.org/pipermail/aztlan/2007-July/003030.html (verified 25 May 2008)

-. 2007b. Entries 16-19, 118 in The Jay I. Kislak Collection at the Library of Congress: A Catalog of the Gift of the Jay I. Kislak Foundation to the Library of Congress, Pp. 1113, 42 (Arthur Dunkelman; with essays by R. Ehrenberg et al.). Library of Congress, Washington D.C.

D’Orlando, K.J. and B.S. Fox. 2004. Tolerability and pharmacokinetics of single and repeated doses of nicotine with the straw, a novel nicotine replacement product. Nicotine \& Tobacco Research 6:63-70

Deal, M. 1998. Pottery Ethnoarchaeology in the Central Maya Highlands. University of Utah Press, Salt Lake City.

de Smet, P.A. and N.M. Hellmuth. 1986. A multidisciplinary approach to ritual enema scenes on ancient Maya pottery. Journal of Ethnopharmacology 16(2-3): 213-262. Esponda Jimeno, Victor Manuel. 1992. El K'awaltic: las ordenanzas de Oxchuc del Visitador Jacinto Roldán de la Cueva, 1674. Anuario del Instituto Chiapaneco de Cultura, 1992, pp. 187-205.

Gabriel, Marianne. 2007. El uso ritual de alcohol, tabaco, cacao e incienso en las ceremonias agrarias de los mayas yucatecos contemporáneos. Estudios de Cultura Maya XXIX:155-184.

Gómez Sánchez, María et al. (2007). "Changeover of authorities in Oxchuc” [Video]. Tseltal Documentation Project. The Archive of the Indigenous Languages of Latin America: www.ailla.utexas.org. Resource: TZH002R005. 
Goodspeed, T.H. 1954. The Genus Nicotiana: Origins, Relationships, and Evolution of Its Species in the Light of Their Distribution, Morphology, and Cytogenetics. Chronica Botanica 16(1-6). Parts 1-5 T.H. Goodspeed. Part 6 T.H. Goodspeed, H-M. Wheeler, and Paul H. Hutchinson. Chronica Botanica Company, Waltham, MA.

Gossen, G. 1980. Chamulas in the World of the Sun: Time and Space in a Maya Oral Tradition. Cambridge University Press, Cambridge.

- 2002. Four Creations: An Epic Story of the Chiapas Mayas. Edited and Translated by G.H. Gossen with contributions by Manuel López Calixto, et al.; illustrations by M.L. Calixto; foreword by M. León-Portilla; afterword by J. Rus. University of Oklahoma Press, Norman.

Groark, K.P. 1997. To Warm the Blood, To Warm the Flesh: The Role of the Steambath in Highland Maya (Tzeltal-Tzotzil) Ethnomedicine. Journal of Latin American Lore 21(1):3-96.

—. 2005. Vital warmth and well-being: steambathing as household therapy among the Tzeltal and Tzotzil Maya of highland Chiapas, Mexico. Social Science \& Medicine $61: 785-795$

-. 2010. Angel in the Gourd: Ritual, Therapeutic, and Protective Uses of Tobacco (Nicotiana tabacum) among the Tzeltal and Tzotzil Maya of Chiapas, Mexico. Journal of Ethnobiology 30(1):5-30.

- 2017. Specters of Social Antagonism: The Cultural Psychodynamics of Dream Aggression among the Tzotzil Maya of San Juan Chamula (Chiapas, Mexico). Forthcoming: Ethos.

Guiteras Holmes, C. 1961. Perils of the Soul: The World View of a Tzotzil Indian. The Free Press of Glencoe, Inc., New York. 
Hayden, Brian. 2004. Signs and Symbols of the Maya. The PARI Journal V(2):7-12.

Henningfield, J.E. and R.M. Kennan. 1993. Nicotine delivery kinetics and abuse liability. Journal of Consulting and Clinical Psychology 61:743-750.

Henningfield, J.E., Radzius, A. \& Cone, E.J. 1995. Estimation of available nicotine content of six smokeless tobacco products. Tobacco Control 4:57-61

Holland, W. 1963. Medicina Maya en los Altos de Chiapas. Instituto Nacional Indigenista, México, D.F.

Houston, Stephen, David Stuart, and Karl Taube. 2006. The Memory of Bones: Body, Being, and Experience among the Classic Maya. University of Texas Press, Austin.

Hunt, E. 1977. The Transformation of the Hummingbird: Cultural Roots of a Zinacantecan Mythical Poem. Cornell University Press, Ithaca.

IARC. 2007. IARC Monographs on the Evaluation of Carcinogenic Risks to Humans, Vol. 89, Smokeless Tobacco and Some Tobacco-specific N-Nitrosamines. World Health Organization International Agency for Research on Cancer, Lyon.

Janiger, O. and M. Dobkin de Rios. 1973. Suggestive hallucinogenic properties of tobacco. Medical Anthropology Newsletter 4(4):6-11.

-1976. Nicotiana an hallucinogen? Economic Botany 30: 149-151.

Kaufman, T. 1972. El Proto-Tzeltal-Tzotzil: Fonología comparada y diccionario reconstruido. Universidad Nacional Autónoma de México, Mexico, D.F. 
Kerr, Barbara and Justin Kerr. 2005. The Way of God L: The Princeton Vase Revisited. Record of the Princeton Art Museum 64: 71-79.

Köhler, U. 1995[1977]. Chonbilal Ch'ulelal - Alma vendida: elementos fundamentales de la cosmología y religion mesoamericanas en una oración en maya-tzotzil. Universidad Nacional Autónoma de México / Instituto de Investigaciones Antropológicas, México, D.F.

Laughlin, R. M. 1975. The Great Tzotzil Dictionary of San Lorenzo Zinacantán. Smithsonian Institution Press, Washington, D.C.

Lehmann, W. (ed.). 1949. Sterbende Götter und christliche Heilbotschaft. Wechselreden indianisher Vornehmer und spanischer Glaubensapostel in Mexiko 1524. Quellenwerke zur Alten Geschichte Amerikas (Bd. 3), Stuttgart.

Loughmiller-Newman, Jennifer A. and Dmitri Zagorevski. N.d. The "House" of Tobacco: Nicotine in a Late Classic Maya Vessel. Forthcoming in Ancient Mesoamerica.

Maffi, L. 1996. Liquor and Medicine: A Mayan case study in diachronic semantics. Journal of Linguistic Anthropology 6(1):27-46.

McGehee, D.S., M.J.S. Heath, S. Gelber, P. Devay and L.W. Role. 1995. Nicotine Enhancement of Fast Excitatory Synaptic Transmission in CNS by Presynaptic Receptors. Science 269:1692-1696.

McGehee, D.S. and L.W. Role. 1996. Memories of nicotine. Nature 383:670-671.

Megged, Amos. 1984. The Sacred Book of Oxchuc: Annihilation and Fusion in MayaTzeltal Religion and Society. Masters of Arts thesis in Comparative Religion, The Hebrew University of Jerusalem. 
-. 1996. Exporting the Catholic Reformation: Local Religion in Early-Colonial Mexico. E.J. Brill: Leiden, The Netherlands.

Mendelson, E.M. 1967. "Ritual and Mythology" In Handbook of Middle American Indians, Vol. 6: Social Anthropology, ed. M. Nash, pp. 392-415. University of Texas Press, Austin.

Méndez Girón, Juan et al. 2008. "The sacred book" [Video]. Tseltal Documentation Project. The Archive of the Indigenous Languages of Latin America: www.ailla.utexas.org. Resource: TZH003R028.

Miller, M.E., and K. Taube. 1993. The Gods and Symbols of Ancient México and the Maya: An Illustrated Dictionary of Mesoamerican Religion. Thames and Hudson, London and New York.

Newhouse, P.A., A. Potter, and A. Singh. 2004. Effects of nicotinic stimulation on cognitive performance. Current Opinion in Pharmacology 4:36-46.

Page Pleigo, J.T. 2005. El Mandato de los Dioses: Etnomedicina entre los Tzotziles de Chamula y Chenalhó, Chiapas. Programa de Investigaciones Multidisciplinarias sobre Mesoamérica y el Sureste / Universidad Nacional Autónoma de México, México D.F.

Pharo, Lars Kirkhusmo. 2014. The Ritual Practice of Time: Philosophy and Sociopolitics of Mesoamerican Calendars. Brill: Leiden and Boston.

Recinos, Adrian (Translator). 1961[1952]. Popol Vuh: antiguas historias del Quiché. FCE, México D.F.

Redfield, R. and A. Villa Rojas. 1934. Chan Kom: A Maya Village. Carnegie Institute of Washington, Publication Number 448, Washington, D.C. 
Redfield, Robert and Alfonso Villa Rojas. 1939. Notes on the Ethnography of Tzeltal Communities of Chiapas. Carnegie Institution of Washington, Publication No. 509, Contribution 28, pp. 107-119.

Renner, C.C., C. Enoch, C. Patten, et al. 2005. Iqmik: a form of smokeless tobacco used among Alaska natives. American Journal of Health Behavior 29(6):588-594.

Robicsek, F. 1972. Smoking Gods: Tobacco in Maya Art, History, and Religion. University of Oklahoma Press, Norman.

Rockwell, Elsie. 2005. Indigenous Accounts of Dealing with Writing. Pp. 5-28 in Language, Literacy, and Power in Schooling (Teresa L. McCarty, ed.). Lawrence Erlbaum Associates, Inc.: Mahwah, New Jersey.

Rockwell, Elsie. 2006. Apropiaciones indígenas de la escritura en tres dominios: Religión, Gobierno y Escuela. Cultura, Escritura \& Sociedad 3:161-218.

Roth, H.D., Roth, A.B., and Liu, X. 2005. Health risks of smoking compared to Swedish snus. Inhalation Toxicology 17:741-748.

Smith, Robert E. 1955. Ceramic Sequence at Uaxactun, Guatemala. Vol. 2. Middle American Research Institute Publication 20. Tulane University, New Orleans.

Staller, John E. and Brian Stross. 2013. Lightning in the Andes and Mesoamerica. New York: Oxford University Press.

Stuart, David. 2005. Glyphs on Pots: Decoding Classic Maya Ceramics. Sourcebook for the 29th Maya Meetings at Texas, The University of Texas at Austin, March 11-16, 2005. 
Thompson, J.E.S. 1946. Some Uses of Tobacco Among the Maya. Notes on Middle American Archaeology and Ethnology 3(61):1-5. Carnegie Institution of Washington, Cambridge, MA.

-. 1970/1990. Maya History and Religion. University of Oklahoma Press, Norman.

Tomar, S.L. and J.E. Henningfield. 1997. Review of the evidence that $\mathrm{pH}$ is a determinant of nicotine dosage from oral use of smokeless tobacco. Tobacco Control 6:219-225

Wilbert, J. 1987. Tobacco and Shamanism in South America. Yale University Press, New Haven.

Zagorevski, Dmitri V. and Jennifer A. Loughmiller-Newman. 2012. The Detection of Nicotine in a Late Mayan Period Flask by Gas Chromatography and Liquid Chromatography Mass Spectrometry Methods. Rapid Communications in Mass Spectrometry 26:403-411. 